\title{
The Emperor Has No Clothes: The Limits of OPEC in the Global Oil Market
}

\author{
Jeff D. Colgan
}

\begin{abstract}
Scholars have long debated the causal impact of international institutions such as the World Trade Organization or the International Monetary Fund. This study investigates Organization of Petroleum Exporting Countries (OPEC), an organization that purports to have significant influence over the market for the world's most important commodity-petroleum. Using four empirical tests, I find that OPEC has little or no impact on its members' production levels. These findings prompt the question of why so many people, including scholars, believe in OPEC's influence over the world's oil supply. The idea of OPEC as a cartel is a "rational myth" that supports the organization's true principal function, which is to generate political benefits for its members. One benefit it generates is international prestige. I test this idea using data on diplomatic representation and find that OPEC membership is associated with increased international recognition by other states. Overall, these findings help one to better understand international regimes and the process of ideational change in world politics.
\end{abstract}

Scholars have long debated the causal impact of international institutions. Existing research considers the impact of the World Trade Organization (WTO) on trade, ${ }^{1}$ the International Monetary Fund (IMF) on fiscal and monetary policies, ${ }^{2}$ and human rights treaties on state behavior. ${ }^{3}$ Notable mostly for its absence within political science is the Organization of Petroleum Exporting Countries (OPEC), an institution that many people believe can and does manipulate the global price of oil. This is surprising. Oil is the world's most important commodity, ${ }^{4}$ and changes in its price are commonly believed to have powerful economic and political consequences. Moreover, OPEC represents an intriguing test case for theories of international cooperation. Like the WTO but unlike human rights treaties, there is a direct material

I thank Michael Aklin, André Bernier, David Bosco, Sarah Bush, Ashley Connor, Sikina Jinnah, Robert Keohane, Kristina Johnson, Moonhawk Kim, James Morrison, Margaret Peters, Margaret Roberts, David Steinberg, Jordan Tama, Felicity Vabulas, Sharon Weiner, and participants at the Princeton University Conference on Environmental Politics, the EPSA 2012 meeting, and the University of WisconsinMadison International Relations Colloquium, for helpful feedback on early versions of this article. Special thanks to David Parker and Laina Stuebner for research assistance. Any remaining errors are my own. I gratefully acknowledge support from American University and the Woodrow Wilson International Center for Scholars.

1. See Rose 2004 and 2007; and Goldstein, Rivers, and Tomz 2007.

2. See Simmons and Hopkins 2005; and von Stein 2005.

3. See Sikkink 2011; and Hafner-Burton and Ron 2009.

4. By "most important commodity market," I mean oil is the most valuable commodity traded internationally, measured by total market. 
reward for collective action in OPEC's case, so one might expect deep cooperation. Popular wisdom also holds that OPEC is influential, but economic studies investigating OPEC's market impact have had difficulty finding conclusive evidence. This generates two questions. First, does OPEC operate as a cartel, meaning that it significantly restricts its members' oil production in order to affect prices? Second, if OPEC is not actually a cartel, why do so many people believe that it is?

The first step is to investigate whether OPEC actually acts as a cartel. ${ }^{5}$ Using some of the same tests that in the past have helped evaluate the impact of the WTO and other organizations, I find that OPEC rarely if ever constrains or influences the oil production rate of its member states. Although this article is not the first to question OPEC's effectiveness in restricting the oil supply, ${ }^{6}$ there is sufficient debate and ambiguity in the existing literature to sustain OPEC's image, even among scholars, as a cartel that manipulates the price of oil by restricting supply. Therefore, I conduct four empirical tests in search of OPEC's effect on oil production, at least two of which are entirely novel. I find that OPEC membership is not significantly correlated with lower oil production once other relevant factors are controlled for. At a minimum, there is no good evidence to believe that OPEC is a cartel, and I shift the burden of proof to those who would claim that OPEC facilitates economic collusion. I make no claim about whether OPEC could restrict oil supply in principle; I simply argue that it does not do so in practice. This is due in part, but not principally, to endemic cheating by OPEC members (that is, oil production in excess of their quotas). A cartel needs to set tough goals and meet them; OPEC sets easy goals and fails to meet even those.

There was one occasion on which OPEC did have a significant impact on the world oil market, namely the 1973 oil crisis, but OPEC's role in the crisis has been greatly misunderstood. That event helped to endow OPEC with a reputation as a manipulator of world oil markets.

If OPEC does not operate as a cartel, why do so many people believe that it does? The idea of OPEC as a cartel is a "rational myth" that supports the organization's true principal function, which is to generate political benefits for its members. Scholars have found that various organizations adopt rational myths, ${ }^{7}$ and OPEC would not be the first international institution to outlive its original mandate. ${ }^{8}$ OPEC's current role is obscured in part by the complexity of the world oil market, in part by the fact that one of its members, Saudi Arabia, probably does have some market power on its own (distinct from the organization to which it belongs), and in part by misdirection by OPEC itself. OPEC's perceived market power is a useful fiction that generates political benefits for its members with domestic and international audiences.

5. A cartel is defined as a group of firms (or states, in this case) that creates agreements about quantities to produce or prices to charge. Mankiw 2011, 351. More details later.

6. As I show, the debate thus far has been principally among economists; the paucity of attention given to OPEC noted earlier describes political science. This disciplinary divergence has consequences: economic analyses of OPEC typically omit important political variables, potentially biasing the results.

7. See McNamara 2002; Boiral 2007; and Meyer and Rowan 1977.

8. See Barnett and Finnemore 1999; Gray 2011; Duffield 1994; and Wallander 2000. 
I test this argument using a cross-national data set on diplomatic recognition, and show that OPEC membership is significantly correlated with increased ambassadorial representation from other countries. Consequently, policy-makers within OPEC have no incentive to undermine the idea that OPEC influences the world oil market. This does not necessarily mean that they are actively lying, but rather that they have an incentive to behave in ways that are consistent with the cartel idea so long as that behavior is not too costly. Other knowledgeable actors outside of OPEC fail to dispel the myth for various reasons. In sum, the story of OPEC is mostly about politics, not economics.

Beyond the intrinsic importance of OPEC and the world oil market, this inquiry offers three important lessons about international politics. First, the fact that such a widespread belief could be wrong sheds light on the process of ideational change and the failure to update beliefs. This contributes to a growing literature suggesting that actors' knowledge of causation, especially in economic affairs, is imperfect. ${ }^{9}$ Second, the case of OPEC offers a complement to understanding international organizations as a product of rational design. ${ }^{10}$ Most accounts assume that there is a good fit between an organization's original mandate and its enduring function, but OPEC's history suggests that at least some organizations are designed long before their eventual function is fully understood. Third, the article fills a gap in the research assessing the impact of institutions, ${ }^{11}$ moving beyond the oft-studied WTO and IMF/World Bank. It contributes to recent work on oil-producing states' participation in international organizations. ${ }^{12}$ Finally, the evidence that OPEC is not a cartel calls into question research in political science that is based on that premise. ${ }^{13}$

\section{Existing Ideas About OPEC}

OPEC was established in 1960. Its founders, modeling it after the Texas Railroad Commission, hoped that it would act as a cartel. ${ }^{14}$ Initially this proved impossible because OPEC member countries did not gain control of their own oil production decisions until the 1970s. OPEC began to assign formal production quotas only in 1982. The organization meets regularly and makes decisions by consensus, which effectively gives each state a veto. ${ }^{15}$ OPEC currently has twelve member states:

9. See Darden 2009; Legro 2005; Blyth 2002; and McNamara 2002.

10. Koremenos, Lipson, and Snidal 2001.

11. See Martin and Simmons 1998; and Botcheva and Martin 2001.

12. See Lesage, Van de Graaf, and Westphal 2010; Ross and Voeten 2011; Rudra and Jensen 2011; Goldthau and Witte 2011; Colgan, Keohane, and Van de Graaf 2012; and Baccini, Lenzi, and Thurner 2013.

13. See Blaydes 2004; and Alt, Calvert, and Humes 1988.

14. See Parra 2004; and Yergin 2008.

15. OPEC can set or change its members' quotas for oil production at any of its regular meetings, or it can do so in an "extraordinary session." Each member state appoints a delegate to represent it at OPEC meetings, typically the Minister of Oil or its equivalent. 
Algeria, Angola, Ecuador, Iran, Iraq, Kuwait, Libya, Nigeria, Qatar, Saudi Arabia, the UAE, and Venezuela. ${ }^{16}$ Collectively, OPEC produced 41 percent of the world total in 2009, though individually even its largest producer has a relatively small market share (Saudi Arabia has 12 percent). ${ }^{17}$ If OPEC were able to cooperate flawlessly, it might exert significant market influence.

The significant oil price increases of the 1970s convinced many observers that OPEC had become the cartel that its founders envisioned. ${ }^{18}$ Krasner even argued in a 1974 article entitled "Oil Is the Exception" that the characteristics of oil made it especially susceptible to an international cartel compared with other commodities. ${ }^{19}$ Yet over time many studies have cast significant doubt on the idea that OPEC is a cartel. ${ }^{20}$ Some scholars suggested a "dominant producer" model, namely that Saudi Arabia alone exerted market power, because it seems to be the only state with sizeable surplus production capacity. ${ }^{21}$ Others simply argued that OPEC had little market impact and that oil prices were the product of other market factors. ${ }^{22}$ More recently, scholars have noted a series of limitations on OPEC's effectiveness. ${ }^{23}$ For instance, Brémond and others found that OPEC is a price taker, not a price setter, in the majority of subperiods that they consider. ${ }^{24}$ Still, none of the critics of the OPEC-as-cartel hypothesis offered a compelling alternative account of the organization's role. ${ }^{25}$

Even as scholars cast doubts on its effectiveness, there was sufficient ambiguity to sustain OPEC's image as a cartel. Kaufman and colleagues answer the question "Does OPEC matter?" (for oil prices and production) in the affirmative, as others do. ${ }^{26}$ Smith finds that "OPEC is much more than a noncooperative oligopoly, but less than a frictionless cartel ( that is, multiplant monopoly)." ${ }^{27}$ Despite pointing to OPEC's limitations, Brémond and colleagues conclude that "OPEC influence has evolved through time" rather than rejecting it as a cartel, and they support the idea that a membership subset sustains OPEC's ability to influence markets, as earlier research argued. ${ }^{28}$

16. Indonesia and Gabon were previously members.

17. BP Statistical Review of World Energy.

18. See Osborne 1976; Seymour 1980; Doran 1980; and Adelman 1982. See also internal US government reactions during the 1970s in Qaimmaqami and Keefer 2011.

19. Krasner 1974.

20. See Griffin 1985; Dahl and Yücel 1991; Alhajji and Huettner 2000; Barsky and Kilian 2004; Reynolds and Pippenger 2010; and Cairns and Calfucura 2012.

21. Moran 1982. Adelman suggests that OPEC wobbles between acting as a dominant firm and as part of a cartel depending on market conditions. Adelman 1982.

22. See Johany 1980; and MacAvoy 1982.

23. See Gülen 1996; Kohl 2002; Kaufman et al. 2004 and 2008; Smith 2005; and Hyndman 2008.

24. Brémond, Hache, and Mignon 2012, 125.

25. For an early suggestion about OPEC's myth making, see Doran, 1977 (chap. 6).

26. See Kaufman et al. 2004 and 2008; Demirer and Kutan 2006; and Bentzen 2007.

27. Smith 2005, 74.

28. See Brémond, Hache, and Mignon 2012; Teece 1982; and Crémer and Salehi-Isfahani 1980. 
This ambiguity leads many scholars to continue to believe that OPEC is a cartel, albeit imperfect. Hyndman asserts "OPEC is obviously a cartel that restricts output in order to obtain super-competitive profits," an assertion shared by other economists. ${ }^{29}$ This is true also among many political scientists. ${ }^{30}$ For instance, Blaydes argues that there is an intra-OPEC bargaining game to divide the cartel's profits, in which oil-rich states allow oil-poor states to cheat on their OPEC quotas to a greater extent than the oil-rich ones do. ${ }^{31}$ Yet Blaydes provides no evidence of cartel profits. Empirically, she studies only the behavior of the OPEC members, and does not compare them with non-OPEC members, so it is not possible to assess how either the oil-rich or oil-poor OPEC states' production behavior differs from other states.

Given the extent of scholarly debate, it is perhaps not surprising that many journalists and policy-makers continue to view OPEC as a cartel. Yet international relations theory offers important reasons to doubt that view. As Downs and colleagues argue, even states that appear to be cooperating might be acting as they would have done even without the agreement, because states design international agreements to avoid requirements for costly adjustments to their behavior. ${ }^{32}$ Thus OPEC quotas, even if strictly obeyed, might not actually require states to deviate significantly from their counterfactual behavior in which no quotas existed.

Consequently, one needs to have a fresh look at the evidence. None of the existing studies provide any direct evidence that OPEC members produce less oil than they would in the counterfactual world in which OPEC did not exist. They typically focus instead on measuring the degree to which production changes in one OPEC member are correlated with production changes in the rest of OPEC, a correlation that could be explained in a variety of other ways, such as common reactions to market conditions. ${ }^{33}$ Moreover, many models do not incorporate relevant political variables, such as the regime type and investment risk of a state, creating the potential for omitted variable bias.

\section{OPEC As Market Manipulator?}

Many observers have noted that cheating on OPEC quotas is widespread, but there are additional problems that are probably even more important. I consider four major tests of OPEC's market impact. I focus on the period since 1982, when OPEC first began to assign quotas ("market allocations") to its members. The tests focus exclusively on OPEC's impact on oil production, rather than oil prices, for two reasons. The first is practical: the relationship between OPEC quotas and

29. See Hyndman 2008, 812; Smith 2005 and 2009; and Simpson 2008.

30. See Ikenberry 1988; Alt, Calvert, and Humes 1988; Lieber 1992; Shaffer 2009; and Sovacool 2011.

31. Blaydes 2004.

32. Downs, Rocke, and Barsoom 1996.

33. See Griffin 1985; Kaufman et al. 2008; and Brémond, Hache, and Mignon 2012. 
world oil prices is fraught with potential endogeneity. ${ }^{34}$ Low oil prices might cause OPEC to lower its production quotas, but if OPEC actually has market power, lower OPEC quotas would cause high oil prices. Thus on its own the (lack of) correlation between OPEC quotas and oil prices does not give one enough information to make valid inferences about its status as a cartel. ${ }^{35}$ Some sophisticated statistical techniques might be used to try to overcome this problem, but they are not satisfying. ${ }^{36}$ The second reason is perhaps even more important: production constraints are a necessary element of cartel behavior. If OPEC is not constraining its members' production, then it is not a cartel, by definition. ${ }^{37}$ Focusing on production allows one to directly investigate the extent of collusion between OPEC members, rather than looking at its indirect effect on prices. Indeed, even if OPEC was somehow affecting market prices without constraining its members' production, it would not be doing so as a cartel.

What evidence should one expect if OPEC is a cartel? Mankiw defines a cartel as a group of firms (or states, in this case) that creates agreements about quantities to produce or prices to charge, and further it "must not only agree on the total level of production but also on the amount produced by each member." 38 This definition implies that a gap between market price and marginal cost of production is not by itself evidence of a cartel..$^{39}$ Instead, one should see signs that the organization is cooperating to restrict production (to drive prices up). One should see the following kinds of evidence: new members of the cartel have a decreasing or decelerating production rate (first test); members should generally produce quantities at or below their assigned quota (second test); changes in quotas should lead to changes in production, creating a correlation (third test); and members of the cartel should generally produce lower quantities (that is, deplete their oil at a lower rate) on average than nonmembers of the cartel (fourth test). Failure to observe any of these phenomena would cast doubt about OPEC's status as a cartel, although none is totally determinative. The fourth test is perhaps the strongest because it is difficult to imagine how an organization that does not restrict output compared with nonmembers could be called a cartelhow else could it increase average prices ${ }^{40}$ To preview the results, OPEC fails all four of the tests.

34. Subsequent sections further discuss the link between oil prices and inferences about OPEC as a cartel. 35. A simple bivariate ordinary least squares (OLS) regression between world oil prices and OPEC's aggregate production target from 1982 through 2009 yields an $R^{2}$ value of just 0.15 .

36. To date, no one has identified a plausible instrumental variable or natural experiment. Other approaches exist but have not produced a widely accepted conclusion on the cartel question. See Dahl and Yücel 1991; Gülen 1996; Alhajji and Huettner 2000; Reynolds and Pippenger 2010; and Brémond et al. 2012.

37. Mankiw 2011, 351.

38. Ibid., 351.

39. Producers who stop producing before marginal costs equal market price (like some OPEC producers, possibly) are not behaving perfectly competitively, but that does not necessarily imply cartelization.

40. One of OPEC's stated goals is to stabilize prices. It is possible that an organization could seek to stabilize prices without affecting the long-run average price or production levels of its members. Yet such an organization could not be considered a classic cartel because it would not be profit maximizing. It 


\section{First Test: Does Joining OPEC Affect Oil Production?}

The first test of OPEC as a cartel is the impact that the organization has on the oil production rates of new members. I adopt a before-and-after methodology, following the event history approach used by Rose in his evaluation of the WTO on its members' trade levels. ${ }^{41}$ If OPEC has a constraining influence on oil production, states that join OPEC should have a decreasing or decelerating oil production rate. Conversely, states that leave OPEC should have an increasing oil production rate.

There is scant evidence that OPEC has such an effect. Figure 1 shows the average oil production rate of all states in the five years before they join OPEC and the five years after they join OPEC. Each state's oil production is standardized to a value of 100 in the year that it joined OPEC so that the relative increase or decrease can be compared. As the graph shows, the average production rate increased at almost an identical rate before and after the state joins OPEC - thereby providing no indication that OPEC has constrained oil production.

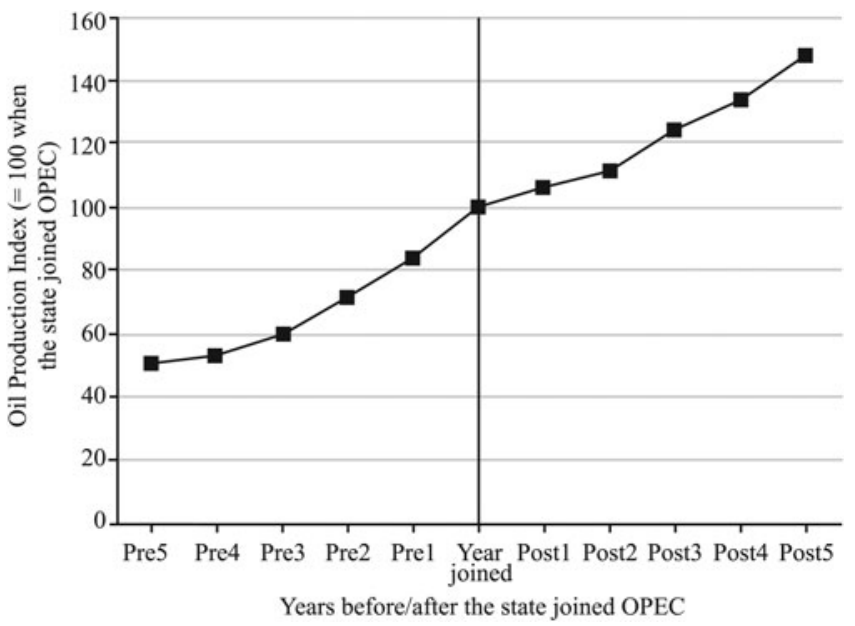

FIGURE 1. Impact of joining OPEC on oil production

\section{Two Tests on the Impact of OPEC Quotas}

The second test focuses on cheating. A strong cartel would have little cheating, but in OPEC cheating is endemic. During the period 1982-2009, the organization as a whole overproduced a staggering 96 percent of the time. I use monthly production

seems unlikely that OPEC is simply trying to stabilize prices without increasing their own profits-even its members do not make that claim.

41. See Rose 2004 and 2007; and Goldstein, Rivers, and Tomz 2007. 
data, drawing on data from the US Energy Information Agency. ${ }^{42}$ Table 1 shows the variation among OPEC members. All but two members overproduced more than 80 percent of the time. Moreover, some OPEC countries manage to avoid having quotas for significant periods of time. ${ }^{43}$ The magnitude of overproduction varies over time and across states, but it is not trivial: on average, the nine principal members of OPEC produced 10 percent more oil than their quotas allowed. ${ }^{44}$ This is equivalent to 1.8 million barrels per day, on average, which is more than the total daily output of Libya in 2009. Even on the relatively rare occasions when member countries are not overproducing, the root cause is often involuntary production constraints such as a strike or accident, rather than a conscious decision by the government to obey its OPEC quota.

TABLE 1. Relationship between OPEC quotas and production, 1982-2009

\begin{tabular}{|c|c|c|c|c|}
\hline \multirow[b]{2}{*}{ OPEC member } & \multirow[b]{2}{*}{$\%$ months production exceeds quota } & \multicolumn{3}{|c|}{ Correlation between production and quota ${ }^{1}$} \\
\hline & & Beta coefficient & $P$-value & $R$-squared \\
\hline Algeria & $100 \%$ & 0.105 & 0.035 & 0.014 \\
\hline Iran & $72 \%$ & 0.002 & 0.981 & 0.000 \\
\hline $\operatorname{Iraq}^{2}$ & $82 \%$ & 0.065 & 0.819 & 0.000 \\
\hline Kuwait & $90 \%$ & 0.106 & 0.450 & 0.002 \\
\hline Libya & $83 \%$ & 0.183 & 0.038 & 0.014 \\
\hline Nigeria & $88 \%$ & 0.138 & 0.383 & 0.002 \\
\hline Qatar & $90 \%$ & 0.118 & 0.245 & 0.004 \\
\hline Saudi Arabia & $82 \%$ & 0.138 & 0.130 & 0.007 \\
\hline U.A.E. & $96 \%$ & -0.140 & 0.170 & 0.006 \\
\hline Venezuela & $77 \%$ & 0.095 & 0.472 & 0.002 \\
\hline OPEC-9 (excludes Iraq) & $96 \%$ & 0.153 & 0.017 & 0.018 \\
\hline
\end{tabular}

1. Values displayed are from bivariate OLS regression of first-differences, where DV = changes in production.

2. Up to March 1998 only. Iraq was not assigned an OPEC quota after March 1998.

One might wonder how much this level of cheating actually undermines the cartel's operation. One possibility is that the OPEC anticipates a certain amount of cheating and sets the quotas accordingly. The real questions are whether OPEC production rates are affected by quotas, and whether they are lower than the counterfactual in which no quotas were set. The remaining tests investigate those questions.

42. EIA estimates can differ from OPEC's reported production data. OPEC's data are not fully credible because they are self-reported by member countries that have an incentive to dissimulate when they are overproducing.

43. Iraq has not had a quota since 1998. Iran, Angola, and Ecuador have also had periods without a quota. OPEC production allocations available at <http://www.opec.org/opec_web/static_files_project/media/ downloads/data_graphs/ProductionLevels.pdf>, accessed 10 November 2013.

44. The nine members are Algeria, Iran, Kuwait, Libya, Nigeria, Qatar, Saudi Arabia, UAE, and Venezuela. Calculated using data from the United States, EIA for actual production, and from OPEC for market allocations, 1982-2009. Note that Smith estimates that overproduction averages just 4 percent using ostensibly the same data (though for a different time period). Smith 2008. 
The third test reveals that OPEC quotas do a poor job of accounting for variation in production levels. Table 1 also shows the R-squared value of a linear bivariate timeseries regression between changes in an OPEC member's production and changes in its quota. ${ }^{45}$ For all but two of the states (Libya and Algeria), changes in the OPEC quota are not correlated with production at standard thresholds of statistical significance. The R-squared for the nine major OPEC producers as a group was just 0.018 , meaning that at most 1.8 percent of the variation in the month-to-month changes in this group's oil production can be explained by changes in their OPEC quotas. In other words, at least 98 percent of the variation is explained by factors other than changes in their OPEC quotas.

Even in the face of this evidence, one could still argue that OPEC acts as a cartel in one of two ways. First, one could argue that anticipation by various actors in the oil market obscure OPEC's constraining effect. For instance, perhaps OPEC members change production levels between OPEC meetings because they anticipate forthcoming changes in the quotas. ${ }^{46}$ Second, one could argue that even if OPEC's quota system is entirely meaningless, OPEC still affects oil production over the long term because it encourages the adoption of a slow depletion policy and underinvestment in production capacity ${ }^{47}$ Both of these propositions have a clear empirical implication: the oil production or depletion rate of OPEC member states ought to be significantly less than the production/depletion rate of comparable non-OPEC members. This leads to my fourth test.

\section{Final Test: Do OPEC Members Have Slow Depletion Rates?}

Depletion rates vary widely around the world. (A country's depletion rate is equal to its oil production divided by its proven oil reserves.) Broadly speaking, depletion rates will vary according to three supply-side factors (in addition to global demand for oil): the business climate of the producing country (for example, companies' technical skills, investment climate, the incidence of war or sanctions, etc.); the "lift costs" of oil production (costs of getting oil to the ground, including exploration); and the government's depletion policy. OPEC membership could affect depletion policy, but so could other factors, such as the state's fiscal needs, the incentives generated by its position in the global market ( or example, as a "dominant firm"), and the time horizons of the political leadership.

I investigate the cross-national variation in depletion rates over a thirty-year period, 1980-2010.48 The analysis includes all forty-two oil-producing states

45. Formally, the dependent variable is the first difference in oil production, and the independent variable is the first difference in oil quota. The observations are monthly, although the values are measured in barrels per day.

46. Parra 2004, 321-22.

47. Smith 2009.

48. BP Statistical Review of World Energy provides data on proven reserves starting only in 1980. 
for which data are available. ${ }^{49}$ Descriptive statistics are in an appendix. ${ }^{50}$ Ordinary least squares (OLS) regression is used on the dependent variable, which is the depletion rate in each state-year. ${ }^{51}$ The models use Huber-White standard errors clustered by state on the premise that standard errors for multiple observations within a state cannot be assumed to be independent of each other. All independent variables are lagged by one year to reduce the potential for endogeneity.

Several explanatory variables are used, reflecting the factors just identified. One is the variable OPEC, a dichotomous measure indicating whether the state is a member of OPEC in a given year, which is of crucial interest to this inquiry. The second is WORLD ECONOMIC GROWTH, measured by that year's annual global GDP growth, as a proxy for global demand for oil that might create incentives for especially high or low depletion rates in a particular year. The third is FISCAL STRENGTH, measured by the natural $\log$ of oil reserves per capita. This variable is included because states with large oil reserves per capita can typically meet the fiscal demands of the government without maximizing production. ${ }^{52}$ Data on oil production and oil reserves are from the BP Statistical Review of World Energy. Fourth, the state's INVESTMENT RISK affects the ease with which international businesses can operate and the extent to which they invest in oil production capacity. ${ }^{53}$ It is measured using the (inverse) risk score from the International Country Risk Guide. Fifth, the state's regime type (as measured by Polity IV) is included, because it could affect the state's depletion policy in a variety of ways. ${ }^{54}$ Sixth, a dichotomous variable, wAR, indicates those state-years in which a state was engaged in a major international war in its territory, such as the Iran-Iraq or Iraq-Kuwait wars. Seventh, another dichotomous variable, SANCTION, indicates observations in which a state was the target of a major international sanction. ${ }^{55}$ LIFT COSTS of production (that is, costs of getting oil to the ground, including exploration) are included only as a robustness check, as I will discuss. ${ }^{56}$

Table 2 presents the results of regression analyses. Model 1 shows a simple bivariate model that indicates that OPEC membership is statistically associated with low depletion rates, as expected by the conventional "OPEC-as-cartel"

49. BP Statistical Review of World Energy provides data on forty-seven oil-producing countries, but Brunei, Chad, Equatorial Guinea, Turkmenistan, and Uzbekistan are not included because of data availability for other variables.

50. Available on the journal's and author's websites.

51. To check robustness, the regressions were also conducted using a tobit model; the results were similar.

52. See Teece 1982; and Crémer and Salehi-Isfahani 1991. My use of this measure follows the convention in previous research. Other measures of fiscal strength such as government debt or expenditure ratios are possible but less preferable because they do not necessarily indicate surplus oil reserves, such as the state's capacity to meet fiscal demands without maximizing production.

53. Jensen and Johnston 2011.

54. See Jensen 2006; and Li 2009.

55. Data from Hufbauer, Schott, Elliott, and Oegg 2007.

56. Data from Waghorn et al. 2006. 
hypothesis. The statistical significance of OPEC membership disappears, however, when other variables are added in the subsequent models. Model 2 shows a baseline model, without taking into account the potential impact of OPEC. As expected, INVESTMENT RISK and FISCAL STRENGTH are negatively correlated with the depletion rate, reflecting the fact that poor investment climates inhibit oil production, and oil-rich states have low fiscal needs and thus long-time horizons for depletion.

TABLE 2. Regression analysis on states' oil depletion rates, 1980-2009

\begin{tabular}{|c|c|c|c|c|c|c|}
\hline & (1) & (2) & (3) & (4) & (5) & (6) \\
\hline OPEC MEMBER - ALL & $\begin{array}{c}-3.9569 \\
(-4.08)^{* *}\end{array}$ & & $\begin{array}{l}-0.733 \\
(-0.76)\end{array}$ & & & $\begin{array}{c}-0.81 \\
(-0.84)\end{array}$ \\
\hline SAUDI ARABIA & & & & $\begin{array}{l}-1.625 \\
(-1.59)\end{array}$ & $\begin{array}{c}-1.734 \\
(-1.26)\end{array}$ & \\
\hline OPEC MEMBER - NON SAUDI & & & & $\begin{array}{l}-0.683 \\
(-0.71)\end{array}$ & & \\
\hline OPEC CORE MEMBER & & & & & $\begin{array}{l}-0.911 \\
(-0.6)\end{array}$ & \\
\hline OPEC NONCORE MEMBER & & & & & $\begin{array}{l}-0.627 \\
(-0.62)\end{array}$ & \\
\hline POLITY SCORE & & $\begin{array}{c}0.039 \\
(0.73)\end{array}$ & $\begin{array}{c}0.034 \\
(0.68)\end{array}$ & $\begin{array}{c}0.03 \\
(0.59)\end{array}$ & $\begin{array}{l}0.028 \\
(0.5)\end{array}$ & $\begin{array}{c}0.052 \\
(0.91)\end{array}$ \\
\hline WORLD ECONOMIC GROWTH & & $\begin{array}{c}0.051 \\
(0.76)\end{array}$ & $\begin{array}{c}0.044 \\
(0.67)\end{array}$ & $\begin{array}{c}0.045 \\
(0.68)\end{array}$ & $\begin{array}{c}0.046 \\
(0.68)\end{array}$ & $\begin{array}{r}0.047 \\
(0.71)\end{array}$ \\
\hline FISCAL STRENGTH & & $\begin{array}{l}-0.992 \\
(-4.42)^{* * *}\end{array}$ & $\begin{array}{l}-0.91 \\
(-3.18)^{* * *}\end{array}$ & $\begin{array}{l}-0.905 \\
(-3.15)^{* * *}\end{array}$ & $\begin{array}{l}-0.892 \\
(-2.68)^{* *}\end{array}$ & $\begin{array}{l}-0.905 \\
(-3.16)^{* * *}\end{array}$ \\
\hline INVESTMENT RISK & & $\begin{array}{l}-0.084 \\
(-2.59)^{* *}\end{array}$ & $\begin{array}{l}-0.079 \\
(-2.33)^{* *}\end{array}$ & $\begin{array}{l}-0.08 \\
(-2.36)^{* *}\end{array}$ & $\begin{array}{l}-0.081 \\
(-2.4)^{* *}\end{array}$ & $\begin{array}{c}-0.079 \\
(-2.37)^{* *}\end{array}$ \\
\hline INTERNATIONAL WAR & & $\begin{array}{l}1.097 \\
(0.8)\end{array}$ & $\begin{array}{c}1.155 \\
(0.86)\end{array}$ & $\begin{array}{c}1.112 \\
(0.83)\end{array}$ & $\begin{array}{c}1.043 \\
(0.69)\end{array}$ & $\begin{array}{c}1.104 \\
(0.86)\end{array}$ \\
\hline INTERNATIONAL SANCTIONS & & $\begin{array}{l}-0.649 \\
(-1)\end{array}$ & $\begin{array}{c}-0.61 \\
(-0.98)\end{array}$ & $\begin{array}{l}-0.654 \\
(-1.05)^{* *}\end{array}$ & $\begin{array}{l}-0.677 \\
(-1.1)\end{array}$ & $\begin{array}{l}-0.57 \\
(-0.92)^{* *}\end{array}$ \\
\hline LIFT COST & & & & & & $\begin{array}{l}-0.17 \\
(-1.09)\end{array}$ \\
\hline Observations & 1286 & 993 & 993 & 993 & 993 & 993 \\
\hline$R$-squared & 0.181 & 0.373 & 0.376 & 0.377 & 0.377 & 0.379 \\
\hline
\end{tabular}

Notes: t-scores in parentheses (robust standard errors clustered by state). $*$ significant at $10 \% ; * *$ significant at $5 \%$; *** significant at $1 \%$.

In Model 3, OPEC membership is reintroduced to the regression. The new variable is not statistically significant and does nothing to improve the explanatory power of the model (the R-squared moves from 0.373 to 0.376 ). The t-statistic is just -0.76 , indicating that one cannot reject the null hypothesis that OPEC membership has no impact on a state's depletion rate.

Thus OPEC members produce oil at more or less exactly the same rates that they could be expected to produce in the absence of OPEC. The findings imply that, to the extent that OPEC members underproduce compared with non-OPEC members, they do so because of other factors in the model (for example, fiscal strength, investment risk) that have nothing to do with their OPEC membership. Some OPEC members might restrict their depletion rate as a conscious act of policy, but they appear to do so out of their own self-interest, without institutional support from OPEC. For 
instance, Saudi Arabia appears to maintain spare production capacity that it uses strategically to alter the oil supply. ${ }^{57}$

Some OPEC members tend to produce oil at rates as fast or faster than comparable non-OPEC members. For instance, Indonesia and Ecuador often had depletion rates higher than the global average despite being members of a "cartel" with the nominal goal of restricting oil production. Other OPEC members, such as Saudi Arabia and the other Gulf monarchies, produced more slowly, but this seems adequately explained by their market position, low fiscal needs, and business inefficiencies. ${ }^{58}$ Note that several countries outside of the OPEC "cartel" had depletion rates that were as low or lower than most OPEC members, again probably because of the poor business and investment climates in those countries. ${ }^{59}$

What about the "dominant producer" hypothesis? Models 4 and 5 in Table 2 suggest that it is plausible that Saudi Arabia has a significantly lower depletion rate than one would otherwise expect, implying that its policy-makers could be consciously choosing a slow depletion rate to affect the world oil market. Moreover, Saudi Arabia varies its depletion rate considerably over time. Its motives for the changes seem to vary from case to case because Saudi Arabia sometimes seeks higher oil prices (for example, 1982-85), greater market share (for example, 198586 ), ${ }^{60}$ or to provide emergency oil supply (for example, in the wake of Iraq's invasion of Kuwait in 1990). To assess the dominant producer idea, Model 4 is applied. It is the same as Model 3 except that it divides the OPEC variable in two: an indicator variable for Saudi Arabia, and one for all other OPEC states. The coefficient for SAUDI ARABIA is more than double the size of the coefficient for the other OPEC states, and although it is still not statistically significant at standard thresholds, it is close (t-score $=1.59$, $\mathrm{p}<0.12$ ). Some scholars have argued that OPEC is divided between a "core" and "noncore" set of member states, in which the core oil-rich states deplete their oil more slowly. ${ }^{61}$ Model 5 tests this possibility by further dividing the OPEC variable into three categories: Saudi Arabia, other OPEC core states (defined as Kuwait, UAE, Qatar, and Libya), and the "noncore" OPEC countries. In Model 5, the coefficient for Saudi Arabia is again the strongest and most negative, followed by the other "core" OPEC countries. However, none of the variables are statistically significant, and only Saudi Arabia's is even close (t-score is 1.26 for Saudi Arabia, compared with 0.60 and 0.62 for the rest of OPEC). Finally, Model 6 controls for LIFT CosTs; the

57. See Yergin 2008; and Parra 2004.

58. Saudi Arabia and the other Gulf monarchies fall into this category. In countries such as Iran and Iraq, low depletion rates are also strongly influenced by the poor business climate in those states, which in turn are affected by factors such as managerial incompetence, wars, corruption, and political risk for investments.

59. Examples include Azerbaijan, Mexico, Equatorial Guinea, and Kazakhstan. Equatorial Guinea and Kazakhstan also have relatively high reserves per capita, suggesting low short-term fiscal needs and longer time horizons.

60. See Yergin 2008; and Parra 2004.

61. Blaydes 2004. See also Teece 1982; Crémer and Salehi-Isfahani 1980 and 1991; and Alhajji and Huettner 2000. 
findings are consistent with Model 3.62 In sum, these models provide little to no evidence that OPEC has any systematic causal effect on depletion rates, and there is some (weak) evidence of Saudi Arabia as a dominant producer.

As in all statistical models, it is impossible to affirm the null hypothesis (that is, to prove that OPEC has no impact) but there is no evidence that OPEC is having a causal impact. One might wonder whether the statistical tests here are too imprecise to identify the effect OPEC is having on its members' depletion rate. To test this idea, suppose that the difference between an OPEC member (except Saudi Arabia) and its baseline predicted oil production (from Model 2) is really caused by a difference in depletion policy, not simply statistical noise. On average, OPEC countries (except Saudi Arabia) produce 6.6 percent less oil than predicted. ${ }^{63}$ In $2009,6.6$ percent of non-Saudi OPEC oil was 1.6 million barrels per day, or 2.0 percent of the world oil market. This is not a large amount, and it is difficult to believe that such an amount is having a major impact on world oil prices, even assuming (1) that it is a conscious policy of the OPEC states and (2) that it induces no supply substitution from non-OPEC oil sources.

One might wonder whether selection bias is a threat to the analysis. OPEC membership is not random. Only states with relatively large oil reserves are likely to join OPEC. One might expect such states to have relatively low depletion rates because states with large oil reserves could meet their fiscal needs even without maximizing oil production. Yet if OPEC "selects for" the states with low depletion rates, that should make it even easier to observe that OPEC states systematically underproduce compared with non-OPEC states in the analyses presented in Table 2. There is no such evidence. The only way that a selection effect could be masking OPEC's impact as a cartel is if the states that join OPEC are systematically likely to have higher depletion rates than non-OPEC members. There is no reason to believe that is true.

One other striking feature of the market for oil is its remarkable resilience to the impact of international events such as wars and economic sanctions. Although there can be little doubt that wars do have impact in some circumstances (for example, Kuwait in 1990), the evidence suggests that those disruptions occur only in the face of truly catastrophic violence and even then are quite short lived. International sanctions, such as those placed on Angola, Libya, Syria, Sudan, and Iran, appear to have had little impact on oil output (although Iraq for some but not all of the 1990s may be an exception to this trend). This does not necessarily indicate the ineffectiveness of economic sanctions, however. Often there were other goals of the sanctions besides restricting oil production, such as limiting the international

62. Unfortunately, there is a lack of publicly released, cross-national time-series data for measuring lift costs. As a proxy, the lift cost data for different countries can be estimated using data from a Goldman Sachs report on the largest 125 upstream development projects under development. Waghorn et al. 2006. The issue of data quality is considered further in the discussion of robustness checks.

63. Calculated by subtracting actual depletion rate minus the postestimation predicted rate from Model 2. 
travel of autocratic leaders or restricting weapons purchases. Additional work is needed to evaluate the true effectiveness of sanctions on oil-exporting states.

The statistical models were subjected to a battery of robustness checks, the full description of which is available in an appendix. ${ }^{64}$ Here I briefly summarize them. I controlled for additional variables such as civil wars, low-intensity civil conflicts, and the Cold War. I changed the dependent variable to the state's production rate (rather than depletion rate). I used alternative measures of oil reserves to account for some known flaws in oil reserves estimates. I used alternative specifications for the regression model, such as a tobit model and panel fixed-effects model. None of these changes materially altered the results in Table 2.

I also tested the possibility that OPEC has an effect on its members' production in only certain time periods or under tight market conditions. To do this, I first identified five-year periods, starting in 1980, and used period-specific variables for each of the key explanatory variables. I also tested OPEC's significance during times of tight market conditions, using the estimated amount of excess oil production capacity available worldwide in a given year. Again, I found no evidence of OPEC's impact.

A plausible interpretation of the results in Table 2 is that OPEC membership is epiphenomenonal to an underlying relationship between the size of a state's oil reserves and its depletion rate. States with large oil reserves per capita are likely to join OPEC, and they are also likely to adopt a slow depletion rate. Yet OPEC itself is doing no causal work on the rate of depletion; the real causal driver is the size of the state's oil reserves.

In sum, I used four tests to try to identify the market impact of OPEC, and each test returns the same basic result: there is no evidence that OPEC is restricting its members' oil production rate as a cartel would. Those who would claim that, on the contrary, OPEC actually is a cartel (even only during some periods) must contend with the analyses presented in this study and provide some robust counterevidence.

\section{Formation of Beliefs About OPEC in 1973}

The events of 1973 are a major contributing factor to people's belief that OPEC is a cartel. That year's oil crisis was one occasion (perhaps the only one) on which OPEC did have a significant impact on the world oil market. Yet OPEC's role in the crisis has been greatly misunderstood.

OPEC took three actions in 1973 that contributed to the increase in prices. First, and perhaps most importantly, OPEC members dramatically raised the "posted prices" of their oil, from $\$ 2.90$ to $\$ 11.65$ per barrel. ${ }^{65}$ Posted prices and market

64. Available on Cambridge University Press's website.

65. Yergin 2008, 607. Prices moved from $\$ 1.80$ in 1970 to $\$ 2.90$ in mid-1973 to $\$ 11.65$ in December 1973. 
prices were not the same thing. Posted prices set the nominal value of the oil extracted by the international oil companies (IOCs) and formed the basis for tax and royalty payments from the IOCs to the oil-producing states. ${ }^{66}$ Market prices were the unitrevenues that the IOCs actually received by selling the crude oil in the downstream market. The change in 1973 increased the IOCs' tax payments, and thus increased market prices. Today, "posted prices" no longer exist in the same way.

Second, OPEC encouraged a wave of nationalizations in the oil industry, including Libya (1970), Algeria (1971-74), Iraq (1972), Venezuela (1974), Kuwait (1975-77), and Saudi Arabia (1973-80). The wave of nationalization meant that the production decisions over much of the world's oil reserves were no longer controlled by the "Seven Sisters," as the big Western IOCs were known. It is difficult to quantify the effect of nationalizations (and concurrent loss of production control by the international companies) on the price of oil, but it seems clear that it unsettled the market and amplified a market expectation that oil would be costly in the future. ${ }^{67}$

Third, some OPEC members implemented a short-term embargo against the United States and others as part of the 1973 Arab-Israeli War. ${ }^{68}$ The embargo started in October 1973 and officially ended five months later. Yet even by the end of 1973, the Arab producers were beginning to relax the production restrictions. ${ }^{69}$ Moreover, oil companies responded to the embargo by rerouting petroleum to offset its impact. ${ }^{70}$ The companies' behavior reflected the fungibility of the world market: since the Arab producers continued to sell into the world market, their oil shipments to other countries freed up oil supply from non-Arab producers that could be sold to the embargoed countries. This is not to say that the supply shift was seamless because much of the world oil supply in 1973 was based on longterm contracts and rerouting was not flawless. Still, on a global scale, the actual magnitude of the supply disruption was both temporary (a few months at most) and relatively small (about 4 percent of total OPEC output, or 2 to 4 percent of total world output). ${ }^{71}$

66. Until October 1973, the IOCs and host governments negotiated the posted price of oil, on the basis of which the IOCs were required to pay royalties and tax payments. In October 1973, OPEC governments unilaterally increased the posted prices, forcing the IOCs to pay higher taxes/royalties if they wished to continue operating in their territories.

67. See Johany 1980; and Sampson 2009.

68. The embargo was declared by the Organization of Arab Petroleum Exporting Countries, and OPEC itself did not participate in the embargo. Several OPEC members continued to sell oil to all customers. See Bronson 2006 and Yergin 2008 for a history of the embargo.

69. See Bronson 2006; and Yergin 2008. In fact, declassified documents show that Saudi Arabia made secret oil shipments to the US military, to ensure that its operations in Vietnam would not be compromised. Brown 1999.

70. Stobaugh 1975.

71. Moran reports that total OPEC output declined by 7 percent. Moran 1987, 598. Even this modest amount seems too large in comparison with other data, for example the rates given by BP Statistical Review of World Energy (given in annual averages) or the US Energy Information Agency (given in monthly averages). The BP data suggest that the impact of the embargo was too small to affect the annual average; the EIA data suggest that the decline between October 1973 and March 1974 was about 4 percent of the average in the previous year. 
Perhaps the biggest impact of the embargo was psychological. The embargo solidified OPEC's image as a cartel and exacerbated fears that the world was running out of oil. The US government compounded this effect by imposing domestic price controls on gasoline, leading to shortages and long lines at gasoline stations. These shortages were a consequence of US domestic policy, not the embargo: if prices had been allowed to rise, the market would have cleared on its own. ${ }^{72}$

Much has changed since 1973. Two of the three actions that OPEC took in 1973 cannot be repeated: posted prices no longer exist, and oil nationalization has already happened in most major producers. Only the third action taken by OPEC members, an embargo, could happen in today's oil market, and in terms of affecting oil prices, it might have been the least important of the three actions. Moreover, oil-consuming countries have put in place a number of safeguards to mitigate the effect of such an embargo. ${ }^{73}$ Without insisting that it is impossible, OPEC is unlikely to ever again influence the oil market as it did in 1973.

Still, the 1973 oil crisis raised OPEC's perceived power to influence oil markets to an almost mythical status. Although in hindsight one can see that the increase in world oil prices and US fuel shortages were not primarily driven by OPEC production controls, the OPEC governments did prove in 1973 that they were capable of cooperation and joint decision making about production (or at least some of them, because not all of them participated in the oil embargo). ${ }^{74}$ Even though the magnitude of the supply disruption was both temporary and relatively small, it sent a powerful signal that OPEC governments could and would cooperate in setting their production levels.

\section{Understanding OPEC's Persistence}

Today, OPEC can be understood as a political club that generates diplomatic and other political benefits for its members, and its cartel reputation is an integral source of political strength for the organization. In 1973, however, all observable signals suggested that OPEC was a cartel: oil prices rose; OPEC members coordinated a cut in oil exports and enforced an embargo on some of their customers; and OPEC explicitly claimed to be a cartel, with its members cooperating with

\section{See Kalt 1981; and Frech and Lee 1987.}

73. Gholz and Press 2010. All of the major oil-importing states have significant commercial and strategic petroleum reserves, of far greater quantities than what existed in 1973. Further, in 1974, the International Energy Agency (IEA) was created with the express purpose of managing oil supply disruptions, and to coordinate releases from the petroleum reserves that all IEA members are required to maintain. Colgan 2009. Finally, long-term contracts mostly have been replaced, making the market more flexible. The effect of an embargo, while not zero, would be mitigated by these innovations. Perhaps not surprisingly, there has not been an international embargo by producers since 1973 (compared with three in the period 1956-73).

74. Saudi Arabia, Iran, Iraq, Abu Dhabi, Kuwait, and Qatar announced production cuts and unilateral increases in posted prices on 16 October 1973. 
each other. ${ }^{75}$ Scholars, journalists, oil companies, and policy-makers agreed. ${ }^{76}$ The diplomatic cables of US State Department officials around the time of the 1973 oil crisis provide ample evidence that policy-makers viewed OPEC as a cartel. ${ }^{77}$

Since the 1970s, popular beliefs have been slow to change. Still, some knowledgeable actors gradually recognized OPEC as a noncartel. For analytical purposes, consider the world as divided into four categories of people. Group A consists of OPEC insiders, who have privileged access to information about the organization's behavior and impact. Group B includes oil market participants outside of OPEC who have a significant financial incentive and proprietary data sources to understand oil markets, such as commodities traders and oil companies. Group C consists of those with political or intellectual incentives to understand OPEC, including government analysts and the few academic scholars who specifically analyzed OPEC's behavior and market impact. Group D is everyone else: journalists, policy-makers, the public, and most scholars, including even scholars who work on oil-related subjects like the resource curse. Senior politicians, such as the US president, probably also fall into Group D. These groups are designed to be collectively exhaustive, arranged loosely by the type of information each group has available to understand OPEC's true role, roughly from best to worst.

It is impossible to know with certainty what individuals in each of these groups actually believe, because thoughts are not directly observable. One can, however, consider actors' incentives, behavior, and other observable information as indirect evidence about each group's beliefs. The observable data shed significant light on how and why OPEC's image as a cartel has persisted over time.

To preview the discussion, I suggest that groups $\mathrm{A}, \mathrm{B}$, and $\mathrm{C}$ have sufficient information to know that OPEC's cartel image is incorrect, but group A benefits from the mistake, group B is primarily interested in a different question, and group $\mathrm{C}$ fails to correct it. Group D quite rationally chooses not to invest time into investigating OPEC's precise causal impact, and instead relies on the other groups for information. Given that no one directly and forcefully contradicts the idea that OPEC is a cartel, the myth persists.

\section{Group A: OPEC Insiders and the Rational Myth}

Group A sustains a "rational myth" about OPEC's influence over the world market for oil. A rational myth is an idea that is illusory or false but persists in part because some actors have incentives to sustain it. ${ }^{78}$ This does not necessarily mean that actors who perpetuate a rational myth are actively lying, but rather that they have an incentive to behave in ways that are consistent with the myth so long as

75. See Claes 2001; Parra 2004; and Yergin 2008.

76. See Krasner 1974; Osborne 1976; Seymour 1980; and Doran 1980.

77. Qaimmaqami and Keefer 2011, 165, 167, 285, 366, 432, 489, 1019.

78. See Boiral 2007; and Meyer and Rowan 1977. 
that behavior is not too costly. Scholars have found that various organizations adopt or conform to rational myths. ${ }^{79}$ Crucially, those most likely to realize OPEC's impotence as a cartel-its own members - are the same actors who are least likely to want to undermine that narrative.

For OPEC members, the belief that OPEC is a cartel generates significant political benefits, both at home and abroad. So long as OPEC is viewed as powerful, its leaders can claim credit at home for their "economic stewardship" of the global economy. Leaders of OPEC member states have sought to take credit for their rising economic fortunes in exactly this way. For example, supporters of Venezuelan President Hugo Chavez, who was elected in 1998 as oil prices were plunging, argued that Chavez revitalized OPEC and thus almost single handedly brought about the rise in world oil prices. ${ }^{80}$ This narrative gave Chavez a significant political asset in Venezuelan domestic politics. Similarly, Iranian leaders have sought to use OPEC to take credit in the eyes of the Iranian public. ${ }^{81}$ OPEC thus serves as a useful tool for state leaders when communicating with their domestic constituency.

In addition, the perceived power of OPEC allows its members to reap political rewards in terms of diplomatic influence and attention paid to them. Perceived power brings prestige, and prestige is the currency of international diplomacy. ${ }^{82}$ One empirical implication of this hypothesis is that OPEC members ought to have greater diplomatic recognition by other countries than comparable non-OPEC countries, all else equal.

To test the idea that OPEC generates diplomatic benefits for its members, I adapted existing models of diplomatic recognition based on Gartzke and Jo's work. ${ }^{83}$ The dependent variable is measured by the presence of an ambassador or other official in State A from State B, using diplomatic data from the Correlates of War (COW) project. ${ }^{84}$ I use the terms "diplomatic recognition" and "diplomatic representation" interchangeably here. In the probit models (columns 1 and 2 in Table 3), the dependent variable is measured dichotomously, coded positively when there is any representative in State A from State B. In other analyses (for example,

79. See McNamara 2002; Boiral 2007; and Meyer and Rowan 1977.

80. See Wilpert 2007, 93-94; Jones 2008, 284; Leech 2001; and Fox 2006.

81. For instance, Iran's delegate to OPEC argued in 2011 that "the global economy has been faced with deep and serious crises and Iran with the cooperation of other OPEC member states, after a careful study of the oil market and through making correct decisions has not allowed crude oil prices to drop under these circumstances." Mohammad Ali Khatibi quoted in "Iran Plays Effective Role in OPEC," Press TV, 28 August 2011. Available at <http://www.presstv.ir/detail/196196.html>, accessed 10 November 2013. Also see "Iran Takes Credit for OPEC Decisions," UPI, 13 June 2011. Available at <http://www.upi.com/Business_News/Energy-Resources/2011/06/13/Iran-takes-credit-for-OPEC-decisions/ UPI-13161307967060/>, accessed 6 November 2011; and Clifford Krauss, "Iran's President to Lead Next OPEC Meeting," New York Times (Internet ed.), 19 May 2011. Available at <http://www.nytimes.com/ 2011/05/20/world/middleeast/20iran.html>, accessed 6 November 2011. Iranian officials argue that OPEC has significant economic accomplishments and that Iranian leadership within OPEC plays a major role in those successes. See OPEC 2010, 8-10.

82. Gilpin 1981.

83. Gartzke and Jo 2009.

84. Bayer 2006. 
column 3), the dependent variable is measured using an ordinal index, which ranges from 0 (no representative) to 3 (ambassador) in State A from State B, with intermediate values for a charge d'affairs (2) or other official (1). The results are consistent regardless of which measure is used.

TABLE 3. Impact of OPEC on diplomatic recognition, 1945-2000

\begin{tabular}{|c|c|c|c|c|c|c|}
\hline & \multicolumn{2}{|c|}{$\begin{array}{l}\text { Diplomatic recognition } \\
\text { (DV is dichotomous) }\end{array}$} & \multicolumn{2}{|c|}{$\begin{array}{l}\text { Diplomatic recognition } \\
\text { (DV is dichotomous) }\end{array}$} & \multicolumn{2}{|c|}{$\begin{array}{c}\text { Diplomatic recognition } \\
\text { (DV is four-point ordinal } \\
\text { scale) }\end{array}$} \\
\hline & Coefficient & $\begin{array}{l}\text { Standard } \\
\text { error }\end{array}$ & Coefficient & $\begin{array}{l}\text { Standard } \\
\text { error }\end{array}$ & Coefficient & $\begin{array}{l}\text { Standard } \\
\text { error }\end{array}$ \\
\hline OPEC MEMBER - STATE A & $0.168 * * *$ & 0.024 & & & $0.148 * * *$ & 0.020 \\
\hline OPEC MEMBER - STATE B & $0.189 * * *$ & 0.024 & & & $0.125 * * *$ & 0.019 \\
\hline SAUDI ARABIA IS STATE A & & & $0.301 * * *$ & 0.066 & & \\
\hline SAUDI ARABIA IS STATE B & & & $0.125 *$ & 0.068 & & \\
\hline OPEC, EXCL. SAUDI - STATE A & & & $0.15 * * *$ & 0.025 & & \\
\hline OPEC, EXCL. SAUDI - STATE B & & & $0.188 * * *$ & 0.025 & & \\
\hline OPEC MEMBER - BOTH & $0.162 * *$ & 0.076 & $0.173 * *$ & 0.076 & $0.125 * *$ & 0.054 \\
\hline OIL PRODUCER - STATE A & $0.271 * * *$ & 0.015 & $0.27 * * *$ & 0.015 & $0.174 * * *$ & 0.012 \\
\hline OIL PRODUCER - STATE B & $0.259 * * *$ & 0.015 & $0.26 * * *$ & 0.015 & $0.184 * * *$ & 0.012 \\
\hline NUCLEAR STATE - STATE A & $0.207 * * *$ & 0.034 & $0.208 * * *$ & 0.034 & $0.259 * * *$ & 0.028 \\
\hline NUCLEAR STATE - STATE B & $0.156 * * *$ & 0.033 & $0.156 * * *$ & 0.033 & $0.277 * * *$ & 0.029 \\
\hline NUCLEAR STATE - BOTH & -0.215 & 0.182 & -0.215 & 0.182 & 0.081 & 0.147 \\
\hline DEMOCRACY - STATE A & $0.037 * * *$ & 0.002 & $0.037 * * *$ & 0.002 & $0.01 * * *$ & 0.002 \\
\hline DEMOCRACY - STATE B & $0.045 * * *$ & 0.002 & $0.045 * * *$ & 0.002 & $0.013 * * *$ & 0.002 \\
\hline DEMOCRACY - BOTH & $0.002 * * *$ & 0.000 & $0.002 * * *$ & 0.000 & $0.002 * * *$ & 0.000 \\
\hline RIVALRY STATUS - STATE A & $0.211 * * *$ & 0.010 & $0.21 * * *$ & 0.010 & $0.108 * * *$ & 0.009 \\
\hline RIVALRY STATUS - STATE B & $0.224 * * *$ & 0.010 & $0.224 * * *$ & 0.010 & $0.109 * * *$ & 0.009 \\
\hline RIVALRY STATUS - DYADIC & $-0.833 * * *$ & 0.075 & $-0.832 * * *$ & 0.075 & $-0.654 * * *$ & 0.057 \\
\hline DISTANCE (LOGGED) & $-0.19 * * *$ & 0.005 & $-0.19 * * *$ & 0.005 & $-0.124 * * *$ & 0.004 \\
\hline ALLIANCE & $0.595 * * *$ & 0.021 & $0.595^{* * *}$ & 0.021 & $0.113^{* * *}$ & 0.017 \\
\hline CINC - STATE A & $7.846^{* * *}$ & 0.471 & $7.846^{* * *}$ & 0.471 & $4.343 * * *$ & 0.360 \\
\hline CINC - STATE B & $10.632 * * *$ & 0.523 & $10.609 * * *$ & 0.524 & $5.336 * * *$ & 0.389 \\
\hline $\mathrm{CINC}$ A $*$ CINC B & -10.335 & 53.666 & -10.115 & 53.709 & $-99.218 * * *$ & 14.704 \\
\hline LAGGED DV & & & & & $0.77 * * *$ & 0.003 \\
\hline Observations (dyad-periods) & 213454 & & 213454 & & 187394 & \\
\hline
\end{tabular}

Notes: Robust standard errors shown, clustered by dyad. Spline of years since last diplomatic recognition included in first two models but not shown. * significant at $10 \%$; * significant at $5 \%$; *** significant at $1 \%$.

Table 3 shows the results. The unit of analysis is a directed dyad, and the time period is 1945-2000. Gartzke and Jo's model uses a number of explanatory factors, including: each state's military capabilities; each state's status as a nuclear power; the political regime type of each state; the geographic distance between the states in the dyad; and whether the dyad contains an alliance and/or a political rivalry. I build on their model by adding variables that indicate whether each state is an OPEC member, plus an additional variable that indicates whether both members of the dyad are OPEC members. I also control for whether the state is an oil producer (regardless of OPEC membership).

The empirical analysis indicates that OPEC membership is strongly and positively correlated with levels of diplomatic recognition, indicating that OPEC members are 
more likely to be diplomatically recognized (and reciprocally, to recognize other states) than comparable non-OPEC members. The results also indicate (in the second model) that this is true for all OPEC members, not just of Saudi Arabia. (Additional tests, not shown, also indicate that OPEC membership is beneficial even for "noncore" OPEC members.) The results are consistent even when the form of the dependent variable is changed to an ordinal measure (ordered probit model, column 3). As in the depletion analysis, the regression models were subjected to a battery of robustness checks. For instance, I included additional variables such as dyadic fixed-effects, a dummy for the Cold War period, and the flow of international trade; I also tried dropping some variables, such as the one for joint OPEC membership; and I tried replacing the oil-producer dummy variable with a continuous measure of oil production (linear and logged). None of these changes materially changed the statistical significance of the OPEC variables (see the appendix). ${ }^{85}$

One striking result is the magnitude of the impact that OPEC has on diplomatic representation. The size of the coefficient for the OPEC variable is roughly the same magnitude as for the nuclear weapons status variable, indicating that OPEC membership has roughly the same impact on diplomatic representation (which postestimation tests confirm). On average, OPEC membership is correlated with an increase in diplomatic representation from nine additional states, compared with an equivalent (oil-producing) country that is not an OPEC member. ${ }^{86}$

For instance, Ecuador is noteworthy because it joined, left, and then rejoined OPEC; no other state has this kind of fluctuation in OPEC membership. Ecuador joined OPEC in 1973, and by 1975 eleven countries had newly sent diplomatic representatives (an ambassador, charge d'affairs, or other representative), whereas only one had withdrawn its representative (Ethiopia). ${ }^{87}$ The eleven countries with new representatives-Canada, Haiti, Luxembourg, East Germany, Poland, Hungary, Bulgaria, Romania, Russia, South Korea, and India—represented a broad crosssection of the world, geographically, economically, and politically. It seems plausible, therefore, that Ecuador found this heightened diplomatic status valuable. By contrast, when Ecuador suspended its OPEC membership in 1992, it sustained a net loss in diplomatic representation, when not one new country sent a representative and Poland withdrew its representative. When Ecuador rejoined OPEC in 2007, it again enjoyed a net gain in diplomatic representation, this time consisting of eighteen new embassies or consulates over the next five years. ${ }^{88}$ Similarly, when Gabon joined

85. Available on Cambridge University Press's website.

86. This is based on the expected marginal probabilities as calculated from the first model in Table 3, multiplied by the average number of states in the system in the years 1960-2000.

87. Diplomatic representation is measured only once every five years in the COW data set, so I describe changes in diplomatic representation in the five-year window within which the state joined or left OPEC. 88. The COW data set stops in 2005, so the 2012 data on diplomatic representatives in Ecuador were collected by the author's research assistant using Internet searches. The nineteen countries with new representatives in Ecuador were: Australia, Austria, Belize, Cyprus, Czech Republic, Denmark, Finland, Greece, India, Indonesia, Ireland, Jamaica, Malta, Nicaragua, Pakistan, Philippines, Poland, Sweden, and Taiwan. Only South Korea withdrew its representative during this period. 
OPEC in 1975, it gained diplomatic representation from nineteen new countries and lost representation from four; ${ }^{89}$ when Gabon left OPEC in 1992, it gained representation from only one country and lost it from four others. ${ }^{90}$

The value of increased diplomatic representation is hard to gauge, but it is not trivial. For instance, many of the new diplomatic connections were with relatively rich countries that therefore represented opportunities for increased trade, investment, and tourism. Specifically, about 40 percent of the countries that sent diplomatic representatives to a new member of OPEC had income (GDP per capita) higher than the world average. Moreover, during the Cold War, the new diplomatic connections spanned the divide between East and West. Many OPEC members were otherwise rather marginal to global geopolitics, so diplomatic connections to both sides of the Cold War could bring valuable information and perhaps diplomatic leverage. Diplomatic recognition also brings a certain amount of status and prestige that is hard to measure objectively. ${ }^{91}$

Furthermore, it appears that the diplomatic value of being an OPEC member increased after the 1973 oil crisis, when OPEC's perceived power and prestige increased dramatically. Before 1973, states that joined OPEC gained diplomatic representation from an average of about two countries for each one that it lost (in the aggregate, sixty new representatives to the seven OPEC members, and thirty-five representatives withdrawn). ${ }^{92}$ After 1973, however, states that joined OPEC gained diplomatic representation from an average of eight countries for each one that it lost (in the aggregate, sixty-four new representatives to three states that joined OPEC, and eight representatives withdrawn). ${ }^{93}$

In sum, the evidence suggests that OPEC generates political benefits for its members, such as international diplomatic recognition. With these benefits riding on the notion that OPEC is a powerful institution, its members gain nothing from exposing OPEC as an ineffective cartel. To the extent that they are aware, they are willing to go along with the rituals of acting as a cartel. There is also the potential for cognitive dissonance, in which policy-makers inside OPEC do not reconcile their understanding of the oil market with their desire to believe in OPEC as a cartel. ${ }^{94}$

89. By 1980, Gabon had new representatives from Mexico, Venezuela, Brazil, Argentina, Netherlands, Austria, Greece, Ghana, Togo, Burundi, Rwanda, Tunisia, Turkey, Saudi Arabia, Qatar, North Korea, Bangladesh, Philippines; it lost representatives from Cuba, Denmark, Chad, and Iran.

90. By 1980, Gabon had a new representative from South Africa; it lost representatives from Kenya, Kuwait, Sao Tome, and North Korea.

91. The prestige value of OPEC membership is not constant across countries. To the extent to which OPEC represents one side in a contest between developed and developing countries, a prospective OPEC member weighs the prestige benefits of membership in accordance to its preferred side.

92. The seven states were Iraq, Iran, Saudi Arabia, Venezuela, Libya, Indonesia, and Algeria. Not included are Kuwait, UAE, and Qatar, which joined OPEC before they gained their independence as sovereign states.

93. The three states were Nigeria, Ecuador, and Gabon. Not included are OPEC membership changes after the COW diplomatic data end in 2005.

94. For instance, a former Secretary General of OPEC insists that OPEC shapes world oil prices: "The control was, and remains, long-distance, erratic, imprecise, and unpredictable-but in the end, very 


\section{Group B: Oil Market Participants}

Group B consists of informed oil market participants outside of OPEC such as commodity traders and oil companies. They have access to proprietary data sources on the precise shipments of oil and have the analytical skills to assess OPEC's behavior and impact. The market participants in group B want to know "does at least one of the members of OPEC have some market influence, at least some of the time?" The answer to that question is probably yes. Saudi Arabia appears to have market power: it claims to have significant spare capacity, which is plausible; it depletes its oil quite slowly and probably far below its marginal cost of production; and it makes major, observable changes to its oil production levels that correlate (imperfectly) with its statements about its desire to loosen or tighten global oil supply. Other states such as UAE and Kuwait might also have market power, though the evidence is less clear. The question of whether at least one member of OPEC has market power is important to non-OPEC market participants because it means that the behavior of OPEC (as a group, not as an organization) can affect market prices and production, and thus the strategies of group B actors.

However that question is different than "does OPEC act as a cartel (in the sense of coordinating production to manipulate prices)?" The answer to this question is almost certainly no. Saudi Arabia can (and apparently does) decide to restrict its production without meaningfully coordinating with anyone, much as a dominant firm might do in a semi-monopolistic market. Some market observers thus label Saudi Arabia a "cartel of one," which is not actually a cartel. ${ }^{95}$ As already demonstrated, OPEC does not facilitate meaningful production coordination. OPEC is a political club, not a functioning cartel.

Consequently, market participants in group B probably understand, to varying degrees, that OPEC is not a cartel, but they do not care. They still pay attention to OPEC for signals about present and future Saudi behavior. This is comparable with the way observers pay attention to the White House press secretary for clues about the president's thinking, even though the press secretary has no real power of his or her own. Thus OPEC's announcements could affect market perceptions, which matter in the short term for commodity traders. ${ }^{96}$ It is rational for market participants to observe OPEC even if they believe that the organization itself does not alter market fundamentals. Instead, they are principally interested in OPEC as shorthand for "the members of OPEC," just as other market analysts are interested in the BRICs as shorthand for "Brazil, Russia, India, and China" without implying that these countries are in some way colluding.

real...The system is slow, clumsy, partly dependent on necessarily inaccurate demand forecasts, and bedeviled by indiscipline within OPEC's ranks. But, by and large, it works." Parra 2004, 321-22.

95. Christopher Swann and Kevin Allison, "Fraction of the Whole," Breakingviews, 14 June 2012. Available at http://blogs.reuters.com/breakingviews/2012/06/14/opec-starting-to-look-like-a-cartel-of-one/, accessed 8 May 2014.

96. See Demirer and Kutan 2006; and Hyndman 2008. 
Having answered the first question (at least one member has market power), the second question (about cartel status) is rather moot for market participants. Market participants have no strong reason to dispute OPEC's status as a cartel. Even if they did, they would have to persuade everyone else, which would take effort that could be spent elsewhere more profitably. Moreover, there are perhaps some benefits to the public's confusion about OPEC. Oil company executives, at least, are happy to have OPEC as a scapegoat for oil prices, which deflects blame away from their own companies. For all these reasons, market participants fail to dispel OPEC's image as a cartel.

\section{Group C: Government Analysts and Scholars Looking Specifically at OPEC}

Group C consists of two subgroups, both of which have incentives to understand OPEC: government analysts and the small set of academic scholars who have directly investigated the extent to which OPEC functions as a cartel. Group C's incentives are principally nonfinancial. Government analysts have access to proprietary or confidential data sources on the precise shipments of oil, whereas academic scholars generally do not, relying only on public data.

First, consider the government analysts. The failure of government analysts to realize that OPEC does not operate as a cartel and/or to forcefully articulate that point to their political masters is surprising and puzzling. It is not entirely clear whether the problem is one of knowledge or of communication. Government analysts are presumably capable of conducting the same analysis this article describes, but to date either that analysis has not been done or it has not been widely disseminated. Personal discussions with various officials in the US government suggest that there is a wide range of beliefs about OPEC, and some analysts are indeed quite skeptical of OPEC's ability to behave as a cartel.

Even so, there is evidence that the modal belief of government analysts is that OPEC is at least a semi-functional cartel. First, many publications by the US government, such as on the Department of Energy's (DOE) website, label OPEC a cartel. ${ }^{97}$ Second, some government analysts explicitly analyze OPEC's effect as a cartel in their published research. ${ }^{98}$ Third, the behavior of the analysts' political leaders is consistent with the belief that OPEC is a cartel. For example, US Secretary of Energy Bill Richardson chose to visit multiple OPEC countries in the late 1990s in a diplomatic effort to affect world oil prices, including those outside

97. Available at <http://energy.gov/management/timeline-events-2003><http://energy.gov/management/ timeline-events-2007> <http://www.fueleconomy.gov/feg/oildep.shtml > <http://www.loc.gov/rr/business/ BERA/issue5/cartels.html> and < http://www1.eere.energy.gov/analysis/pdfs/strategic_program_review. pdf>, accessed 10 November 2013.

98. See Greene and Leiby 1993; and Greene et al. 2007. These publications are consistent with observations made by government analysts around the time of the 1973 oil crisis. See Qaimmaqami and Keefer 2011. 
of the Middle East (more on this later) ${ }^{99}$ If Richardson and the analysts who advise him did not believe that OPEC is a cartel, it is not clear why he would make such an effort: visiting OPEC countries such as Venezuela, Nigeria, or Ecuador makes no sense if they are not cartel members. Fourth, former CIA director James Woolsey (who might be considered both a government analyst and political leader) explicitly identifies OPEC as a cartel. ${ }^{100}$ Collectively this evidence suggests that many government analysts believe OPEC is a cartel. ${ }^{101}$

It might seem surprising that intelligent, sophisticated analysts could hold incorrect causal beliefs even when corrective evidence is available. Yet there is a growing body of research suggesting that actors' knowledge of causation, especially in economic affairs, is imperfect. ${ }^{102}$ Darden, for instance, finds that "actors inherently lack objective knowledge of the relationship between cause and effect in economics and other matters in the world." ${ }^{103}$ Actors sometimes continue with an established set of economic ideas for decades before deciding it is wrong. For instance, seventy years elapsed between Adam Smith's free trade theory (1776) and its first real implementation (British Corn Laws, 1846). Other historical examples abound, including classical versus Keynesian fiscal policy or import-substitution versus export-oriented trade policies. Thus one should avoid such a strong form of rationalism that one assumes policy-makers never make a mistake. Unfortunately, government intelligence failures are not as uncommon as one might hope, due to various bureaucratic and cognitive constraints. ${ }^{104}$

In addition, the mistake should be understood in the context of the question's analytic complexity. For instance, in the first half of 2008, oil prices rose to above $\$ 140$ per barrel in July, before plunging to below \$40 per barrel in January 2009. OPEC's oil production rose significantly as prices increased, and fell when prices were falling. Many argued that this period was evidence of OPEC's cartel behavior. There are three problems with this argument. First, OPEC's behavior might be simply a profit-maximizing response to price changes. True, OPEC production fell in the July-January period as prices fell, but so did non-OPEC production: by more than 1 million barrels per day (bpd) worldwide, including a 258,000 bpd decline in the United States-hardly a cartel country. Several non-OPEC states such as Mexico, Norway, and Azerbaijan had production declines that were larger than those in eight out of twelve OPEC states. Second, only one OPEC country (Saudi Arabia) made an especially large production cut reduction, which is hardly evidence of cartel coordination. There is no evidence that cuts made by other OPEC members were larger than a perfectly competitive market response. Third, most of the OPEC

99. Richardson 2005, 269.

100. Woolsey and Korin 2008.

101. If these analysts do not actually believe that OPEC is a cartel, one is left to infer that they are misleading the American public.

102. See Darden 2009; Legro 2005; Blyth 2002; McNamara 2002; Boiral 2007; and Chwieroth 2009.

103. Darden 2009, 9.

104. Jervis 2010. 
production changes came before significant changes were made to OPEC quotas; the quota changes merely ratified earlier production decisions by individual countries. This example points to a broader problem with informal attempts to infer OPEC's impact in the face of frequent price volatility. If OPEC production increases as prices are falling, some will infer that OPEC is causing prices to fall; but if instead OPEC production decreases, some will infer that OPEC's impact is delayed, and will cause a price increase that arrives some months later. Frequent price movements (and no clear counterfactual) mean that it is hard to tease out OPEC's true effect. Thus one cannot directly infer OPEC's status as a cartel by examining the raw oil market data. The question demands a sophisticated analysis, and as it turns out, even scholars cannot agree.

Scholars of OPEC are the second subgroup. Like the government analysts, they have incentives to understand OPEC's role. Unfortunately, scholars face at least two obstacles to dispelling the myth of OPEC's cartel status. First, the data available to scholars are not always good. The data used in this article (especially for the third and fourth tests) were not available in the 1970s and 1980s when the scholarly debate about OPEC's role in the world oil market first occurred. Still, this excuse is weak, because sufficient public data have been available since the 1990s.

A second obstacle is that scholars have difficulty reaching a unanimous or even dominant view on questions that involve complex causality and where experimental testing in laboratory conditions is infeasible. Indeed, scholars face professional incentives to generate debate by providing novel arguments and contrarian empirical findings. The topic of OPEC as a cartel is causally complex. Not surprisingly, consensus has been difficult to achieve, as the literature reviewed earlier indicates. True, recent academic work raises a growing number of doubts about OPEC's causal impact on oil markets. ${ }^{105}$ Nonetheless, there are some scholars who insist on OPEC's role as a cartel even in recent publications. ${ }^{106}$ Given the ongoing debate among scholars, and the fact that academics often find it difficult to sway public opinion even on matters where there is considerable scholarly agreement (for example, on trade policy), it is not surprising that they have failed to persuade nonacademics to change their view about OPEC.

\section{Group D: Everyone Else}

Group D consists of everyone else: journalists, policy-makers, the public, and most scholars, including most political scientists. The question of whether OPEC is a cartel is not something that deeply affects the day-to-day lives of people in group D. Quite rationally, they choose not to devote time and effort into investigating

105. See Reynolds and Pippenger 2010; Goldthau and Witte 2011; Cairns and Calfucura 2012; Brémond, Hache, and Mignon 2012; Victor 2008; and Barsky and Kilian 2004.

106. See Smith 2005 and 2009; Kaufman et al. 2004 and 2008; Hyndman 2008; Demirer and Kutan 2006; Bentzen 2007; and Simpson 2008. 
this question because they have other jobs and concerns. Instead, they rely on the other groups (A, B, and C) for information on which to base their beliefs.

Consequently, most people do not realize that OPEC is not a cartel. Their error is facilitated because OPEC itself perpetuates the "rational myth" that it is a cartel, for the reasons I have given: members enjoy prestige and political benefits that are based on that myth. Moreover, nonspecialists tend to conflate the question "is OPEC a cartel?" with the question "does at least one of the members of OPEC have some market influence?" Although the answers to those questions are quite different, they appear sufficiently similar that many people confuse the two. Group A benefits from that confusion; group B is not interested in correcting it; and group $\mathrm{C}$ continues to debate the issue. So the mistake continues.

Many journalists have a sufficiently deep understanding of oil markets to realize that OPEC is weak as an organization, and that any market power that its members have is driven largely by Saudi Arabia. Some but certainly not all of the news coverage of OPEC reflects this understanding. ${ }^{107}$ Still, this awareness is not sufficiently widespread to overturn the enduring image of OPEC as a cartel.

State leaders and other senior government officials also appear to fall into group D. State leaders do, of course, have access to the best data and expertise on OPEC and oil markets, at least indirectly. However, the government analysts on whom state leaders rely do not appear to clarify OPEC's role. Thus leaders are probably like most other people, believing in OPEC's ability to function as a cartel.

One cannot directly observe leaders' beliefs but clues can be obtained from their memoirs. For instance, in one of the few mentions of OPEC in Bill Clinton's autobiography, he writes "Energy was a huge issue [in 1980] because of OPEC's steep increase in the price of oil, which raised prices for everything else, too."108 Elsewhere he writes, "[In 2000] I wanted to see the price stabilize at between $\$ 20$ and $\$ 22$ a barrel and hoped OPEC could increase production enough to do that." 109 Those statements seem to indicate that Clinton viewed OPEC as a cartel, but they are not definitive. Richardson, Clinton's secretary of energy, is somewhat clearer in his memoirs, stating that "What we faced was a combination of OPEC power in the marketplace, our dependence on imported oil, and demand pressures." ${ }^{110} \mathrm{He}$ also recalls that "Over the course of the year [2000], I made four trips to various OPEC countries, principally the ones in the Middle East, to jawbone for hikes in output that would moderate the increase in prices." ${ }^{111}$ Richardson's efforts to persuade multiple OPEC countries (including those outside of the Middle East)

107. See "Oil Prices: Keeping It to Themselves." The Economist (Internet ed.), 31 March 2012. Available at <http://www.economist.com/node/21551484>, accessed 6 December 2012; and Clifford Krauss, "Split by Infighting, OPEC Keeps a Cao on Oil," New York Times (Internet ed.), 8 June 2011. Available at <http:// www.nytimes.com/2011/06/09/business/global/09opec.html>, accessed 6 December 2012.

108. Clinton 2005, 268.

109. Ibid., 900. On the same page, Clinton writes: "I spoke with King Fahd of Saudi Arabia about the possibility of OPEC increasing its production."

110. Richardson 2005, 266.

111. Ibid., 269. 
to alter their oil production suggests that he believed OPEC to be a cartel with significant market power, though he never says so explicitly. The beliefs of Clinton and Richardson thus appear to be consistent with those of State Department officials around the time of the 1973 oil crisis. ${ }^{112}$

At any rate, state leaders do not publicly contradict OPEC's image as a cartel, which has important consequences, mostly negative. I discussed one of those consequences earlier: domestic audiences in oil-producing countries tend to give credit to OPEC leaders such as Venezuelan President Chavez for raising the price of oil, even though there is no real evidence that he actually caused such a change. A second example is that many people outside of oil-producing countries are psychologically disposed to pay more attention to OPEC members like Iran or Venezuela when prices are high or rising. This might even generate a tendency for diplomats to defer to OPEC members and offer favors in exchange for promises of increased or decreased OPEC oil production. ${ }^{113}$ Some studies suggest that, regardless of whether policy-makers actually should let oil politics affect their policies, they do in fact behave that way. ${ }^{114}$ For instance, policy-makers are willing to incur considerable material costs in order to increase oil imports from one country (for example, a friendly neighbor) or lower them from another (for example, a potential risky supplier), despite the tendency of a fungible world market to readjust the flow of oil to reach equilibrium. ${ }^{115}$

A third example of the negative consequences of misunderstanding OPEC comes from legislative politics. Politicians in the United States and other oil-importing states blame OPEC for manipulating world oil markets, especially during times of high oil and gasoline prices. For instance, the No Oil Producing Exporting Cartels (NOPEC) Act of 2004 introduced in the US Senate served as a rallying point for those who sought to blame OPEC. ${ }^{116}$ Other NOPEC bills have been introduced at least fifteen times since 1999, though to date none have passed. ${ }^{117}$ The continued introduction of these bills distracts Congress and the public, thereby imposing a significant opportunity cost on the political system. ${ }^{118}$

\section{OPEC as a Political Club}

It appears that some actors recognize that OPEC's image as a cartel is flawed but they do not dispel that image for various reasons. Consequently, the public (group D) continues to view OPEC as an economic cartel rather than as a political club.

112. Qaimmaqami and Keefer 2011. See note 75.

113. Richardson 2005, 266-74.

114. Clayton and Levi 2012.

115. Arguably there might be war-time benefits to manipulating oil imports in this way, but those benefits are highly dubious. See Gholz and Press 2010.

116. Reinker 2005.

117. Verrastro et al. 2011.

118. Scapegoating is probably not limited to the legislative. President Carter's advisors urged him to cast OPEC as a threatening cartel and thereby blame OPEC for American economic problems. Epstein 1983. 
Understanding OPEC as a political club that generates benefits for its members helps explain the organization's persistence in world politics despite its failure as a cartel. It also helps to answer other questions. One such issue is the variation in OPEC's membership. In the 1970s, OPEC enjoyed a certain level of prestige when developing countries saw it as an organization that "took on" the developed countries and won (by raising oil prices). Several oil-exporting developing countries that were not already members wanted into the club: Ecuador and Gabon joined the organization in 1973 and 1975 respectively, only to leave the organization as its prestige fell in the 1990s. Then in the 2000s, with oil prices on the rise, OPEC membership became fashionable again: Ecuador rejoined, Angola was accepted as a new member in 2007, and Sudan sought membership, although it has not yet been accepted. This variation in OPEC membership is counterintuitive behavior if OPEC is a cartel because membership in the organization would be most costly (in terms of forgone oil sales, to the extent that such exist) at times when oil prices are high. The fluctuations in OPEC's membership, which correlate with oil prices, make more sense when viewed from the perspective of the perceived political clout and prestige of the organization.

Viewing OPEC as a political club is also consistent with some anecdotal evidence about how states perceive OPEC membership as a signal of status and prestige. For instance, when Angola joined the organization in 2007, it took out full-page advertisements in The Economist to announce that it had joined OPEC and should be seen as a country of rising importance. Implicitly, the advertisements tied these two claims together: that is, Angola was rising in importance in part because it had joined OPEC.

In sum, the story of OPEC's continued existence is primarily a political one. It is based largely on the perpetuation of a rational myth. Still, it is not necessarily true that OPEC is useless. OPEC probably facilitates information sharing and lowers transaction costs between states, like many other international regimes. ${ }^{119}$ For instance, OPEC has long served as a forum for sharing strategies for dealing with the international oil companies, best practices for writing contracts, and approaches to tax policy. ${ }^{120}$ OPEC members also share predictions about the oil market, which are important for investment decisions. Overall, though, OPEC's chief purpose appears to be political.

\section{Conclusion}

OPEC quotas are irregularly applied, frequently ignored by its members, and have at most a modest effect on actual production. Still, many scholars and policy-makers

119. Keohane 1984.

120. For example, a 1962 report commissioned by OPEC revealed to its members the extent of oil company profits and the lack of a logical economic basis for posted prices. Since tax and royalty payments were based on posted prices, the report had major implications for OPEC member governments' revenues.

See Parra 2004; and Skeet 1991. 
continue to believe that OPEC has great power over oil markets. This is not to suggest that individual members of OPEC have no market power; indeed, probably Saudi Arabia has such power on its own. One might say that OPEC probably has market power because it includes Saudi Arabia, but only in that sense; the findings in this article undermine the idea that the OPEC as an organization manipulates the world oil supply.

Given that OPEC's false image as a cartel appears to generate political benefits for its members, one might wonder why other commodity producers do not seek to emulate it. One can only speculate, but oil producers seem to have at least three advantages. First, one of their members (Saudi Arabia) probably does have significant market power, which is not necessarily true of states in other commodity markets. Second, the oil crisis in 1973 had a powerful demonstration effect; nothing comparable has occurred in other commodity markets. Third, oil is a commodity on which actors place significant strategic weight, which is not necessarily true of bananas or coffee. For all these reasons, a cartel of oil-producers might seem more plausible and worthy of attention than a cartel of other commodities.

My findings have implications for both theory and practice. For theory, the fact that a widespread belief about the world's most important commodity market appears to be wrong should alter how scholars study international political economy. One implication is that scholars should be careful about how the bargaining dynamics within OPEC are studied and conceptualized because they do not occur within the context of a classic economic cartel. ${ }^{121}$ Second, OPEC appears to be an important case within the category of international regimes that have outlived their original mandates. ${ }^{122}$ Third, this article contributes to the research suggesting that actors' knowledge of causation is imperfect. ${ }^{123}$ My research offers a new account of OPEC as a political club, rather than as an economic cartel.

Finally, the case of OPEC offers a complement to understanding international organizations as a product of rational design. ${ }^{124}$ Indeed, at least some organizations are designed long before their eventual function is fully understood, and members' understanding of their purposes probably changes over time. The OPEC case thus reinforces the notion that international organizations often serve purposes other than to solve coordination games. ${ }^{125}$

In the realm of practical politics, journalists and pundits should stop using the assumption that OPEC's actions are key drivers of world energy markets. They are not. Most of the credit or blame for rising oil prices in recent years rests with the energy demands of new Asian customers, not diabolic moves by OPEC. Moreover, policymakers in oil-importing countries should stop being so fearful and resentful of OPEC. Legislation such as the various "NOPEC" bills in the US

121. See Blaydes 2004; and Alt, Calvert, and Humes 1988.

122. See Barnett and Finnemore 1999; Gray 2011; Duffield 1994; and Wallander 2000.

123. See Darden 2009; Legro 2005; Blyth 2002; and Morrison 2012.

124. Koremenos, Lipson, and Snidal 2001.

125. Snidal 1985. 
Congress may be useful for scoring political points, but they have little bearing on the reality of the global oil markets. With the world price of oil set by market forces almost entirely outside of its control, OPEC is along for the ride like everyone else.

\section{Supplementary material}

For supplementary material for this article, please visit http://dx.doi.org/10.1017/ S0020818313000489.

\section{References}

Adelman, Morris. 1982. OPEC as a Cartel. In OPEC Behavior and World Oil Prices, edited by James M. Griffin and David J. Teece, 37-63. London: Allen and Unwin.

Alhajji, A.F., and David Huettner. 2000. OPEC and Other Commodity Cartels: A Comparison. Energy Policy 28 (15):1151-64.

Alt, James E., Randall L. Calvert, and Brian D. Humes. 1988. Reputation and Hegemonic Stability: A Game-Theoretic Analysis. American Political Science Review 82 (2):445-66.

Baccini, Leonardo, Veronica Lenzi, and Paul Thurner. 2013. Global Energy Governance: Trade, Infrastructure, and the Diffusion of International Organizations. International Interactions 39 (2): 192-216.

Barnett, Michael N., and Martha Finnemore. 1999. The Politics, Power, and Pathologies of International Organizations. International Organization 53 (4):699-732.

Barsky, Robert B., and Lutz Kilian. 2004. Oil and the Macroeconomy Since the 1970s. Journal of Economic Perspectives 18 (4):115-34.

Bayer, Resat. 2006. Diplomatic Exchange Dataset, v2006.1. Available at <http://correlatesofwar.org >. Accessed 10 November 2013.

Bentzen, Jan. 2007. Does OPEC Influence Crude Oil Prices? Testing for Co-movements and Causality Between Regional Crude Oil Prices. Applied Economics 39 (11):1375-85.

Blaydes, Lisa. 2004. Rewarding Impatience: A Bargaining and Enforcement Model of OPEC. International Organization 58 (2):213-37.

Blyth, Mark. 2002. Great Transformations: Economic Ideas and Institutional Change in the Twentieth Century. Cambridge: Cambridge University Press.

Boiral, Olivier. 2007. Corporate Greening Through ISO 14001: A Rational Myth? Organization Science 18 (1):127-46.

Botcheva, Liliana, and Lisa L. Martin. 2001. Institutional Effects on State Behavior: Convergence and Divergence. International Studies Quarterly 45 (1):1-26.

Brémond, Vincent, Emmanuel Hache, and Valerie Mignon. 2012. Does OPEC Still Exist as a Cartel? An Empirical Investigation. Energy Economics 34 (1):125-31.

Bronson, Rachel. 2006. Thicker than Oil: America's Uneasy Partnership with Saudi Arabia. New York: Oxford University Press.

Brown, Anthony Cave. 1999. Oil, God, and Gold: The Story of Aramco and the Saudi Kings. Boston: Houghton Mifflin.

Cairns, Robert, and Enrique Calfucura. 2012. OPEC: Market Failure or Power Failure? Energy Policy 50: 570-80. 
Chwieroth, Jeffrey M. 2009. Capital Ideas: The IMF and the Rise of Financial Liberalization. Princeton, NJ: Princeton University Press.

Claes, Dag Harald. 2001. The Politics of Oil-Producer Cooperation. Boulder, CO: Westview Press.

Clayton, Blake, and Michael Levi. 2012. The Surprising Sources of Oil's Influence. Survival 54 (6): 107-22.

Clinton, Bill. 2005. My Life. New York: Random House.

Colgan, Jeff D. 2009. The International Energy Agency: Challenges for the Twenty-first Century. GPPI Policy Paper Series No. 6. Berlin: Global Public Policy Institute.

Colgan, Jeff D., Robert O. Keohane, and Thijs Van de Graaf. 2012. Punctuated Equilibrium in the Energy Regime Complex. Review of International Organizations 7 (2):117-43.

Crémer, Jacques, and Djavad Salehi-Isfahani. 1980. A Theory of Competitive Pricing in the Oil Market: What Does OPEC Really Do? CARESS Working Paper 80-4. Pittsburgh: University of Pennsylvania.

- 1991. Models of the Oil Market. Amsterdam: Harwood.

Dahl, Carol, and Mine Yücel. 1991. Testing Alternative Hypotheses of Oil Producer Behavior. Energy Journal 12 (4):117-38.

Darden, Keith A. 2009. Economic Liberalism and Its Rivals the Formation of International Institutions Among the Post-Soviet States. Cambridge: Cambridge University Press.

Demirer, Riza, and Ali M. Kutan. 2006. Does OPEC Matter After 9/11? OPEC Announcements and Oil Price Stability. Unpublished manuscript, Southern Illinois University-Edwardsville.

Doran, Charles. 1977. Myth, Oil, and Politics. New York: Free Press (MacMillan).

1980. OPEC Structure and Cohesion: Exploring the Determinants of Cartel Policy. Journal of Politics 42 (1):82-101.

Downs, George W., David M. Rocke, and Peter N. Barsoom. 1996. Is the Good News About Compliance Good News About Cooperation? International Organization 50 (3):379-406.

Duffield, John S. 1994. NATO's Functions After the Cold War. Political Science Quarterly 109 (5): 763-87.

Epstein, Edward Jay. 1983. OPEC: The Cartel That Never Was. The Atlantic, March.

Fox, Michael. 2006. President Chavez Hosts 141st OPEC Meeting in Caracas. venezuelanalysis.com, 3 June. Available at <http://venezuelanalysis.com/analysis/1771>. Accessed 18 October 2011.

Frech, H.E., III, and William C. Lee. 1987. The Welfare Cost of Rationing-by-Queuing Across Markets: Theory and Estimates from the US Gasoline Crises. Quarterly Journal of Economics 102 (1):97-108.

Gartzke, Erik, and Dong-Joon Jo. 2009. Bargaining, Nuclear Proliferation, and Interstate Disputes. Journal of Conflict Resolution 53 (2):209-33.

Gholz, Euegene, and Daryl G. Press. 2010. Protecting "The Prize": Oil and the US National Interest. Security Studies 19 (3):453-85.

Gilpin, Robert. 1981. War and Change in World Politics. New York: Cambridge University Press.

Goldstein, Judith L, Douglas Rivers, and Michael Tomz. 2007. Institutions in International Relations: Understanding the Effects of the GATT and the WTO on World Trade. International Organization 61 (1):37-67.

Goldthau, Andreas, and Jan Martin Witte. 2011. Assessing OPEC's Performance in Global Energy. Global Policy 2 (s1):31-39.

Griffin, James M. 1985. OPEC Behavior: A Test of Alternative Hypotheses. American Economic Review 75 (5):954-63.

Gray, Julia. 2011. Life, Death, or Zombies? The Survival and Revival of International Organizations. Unpublished manuscript, University of Pennsylvania, Pittsburgh.

Greene, David L, and Paul N. Leiby. 1993. The Social Costs to the US of Monopolization of the World Oil Market, 1972-1991. Oak Ridge, TN: Oak Ridge National Laboratory.

Greene, David L, Paul N. Leiby, Philip D. Patterson, Steven E. Plotkin, and Margaret K. Singh. 2007. Oil Independence: Achievable National Goal or Empty Slogan? Transportation Research Record: Journal of the Transportation Research Board 2017:47-53.

Gülen, Salih Gürcan. 1996. Is OPEC a Cartel? Evidence from Cointegration and Causality Tests. Energy Journal 17 (2):43-58. 
Hafner-Burton, Emilie M., and James Ron. 2009. Seeing Double: Human Rights Impact Through Qualitative and Quantitative Eyes. World Politics 61 (2):360-401.

Hufbauer, Gary, Jeffrey Schott, Kimberly Elliott, and Barbara Oegg. 2007. Economic Sanctions Reconsidered. Washington, DC: Peter G. Peterson Institute for International Economics.

Hyndman, Kyle. 2008. Disagreement in Bargaining: An Empirical Analysis of OPEC. International Journal of Industrial Organization 26 (3):811-28.

Ikenberry, G. John. 1988. Reasons of State: Oil Politics and the Capacities of American Government. Ithaca, NY: Cornell University Press.

Jensen, Nathan M. 2006. Nation-States and the Multinational Corporation: A Political Economy of Foreign Direct Investment. Princeton, NJ: Princeton University Press.

Jensen, Nathan M., and Noel P. Johnston. 2011. Political Risk, Reputation, and the Resource Curse. Comparative Political Studies 44 (6): 662-88.

Jervis, Robert. 2010. Why Intelligence Fails: Lessons from the Iranian Revolution and the Iraq War. Ithaca, NY: Cornell University Press.

Johany, Ali. 1980. The Myth of the OPEC Cartel: The Role of Saudi Arabia. Dhahran, Saudi Arabia: University of Petroleum and Minerals.

Jones, Bart. 2008. Hugo! The Hugo Chavez Story from Mud Hut to Perpetual Revolution. Hanover, NH: Steerforth.

Kalt, Joseph. 1981. The Economics and Politics of Oil Price Regulation: Federal Policy in the PostEmbargo Era. Cambridge, MA: MIT Press.

Kaufmann, Robert K., Andrew Bradford, Laura H. Belanger, John P. McLaughlin, and Yosuke Miki. 2008. Determinants of OPEC Production: Implications for OPEC Behavior. Energy Economics 30 (2):333-51.

Kaufmann, Robert K., Stephan Dees, Pavlos Karadeloglou, and Marcelo Sanchez. 2004. Does OPEC Matter? An Econometric Analysis of Oil Prices. Energy Journal 25 (4):67-90.

Keohane, Robert. 1984. After Hegemony: Cooperation and Discord in the World Political Economy. Princeton, NJ: Princeton University Press.

Kohl, Wilfrid L. 2002. OPEC Behavior, 1998-2001. Quarterly Review of Economics and Finance 42 (2): 209-33.

Koremenos, Barbara, Charles Lipson, and Duncan Snidal. 2001. Rational Design: Looking Back to Move Forward. International Organization 55 (4):1051-82.

Krasner, Stephen D. 1974. Oil is the Exception. Foreign Policy 14:68-84.

Leech, Garry. 2001. The Chávez Factor. Colombia Journal. 26 March. Available at <http://colombiajournal.org/colombia56.htm>. Accessed 18 October 2011.

Legro, Jeffrey. 2005. Rethinking the World: Great Power Strategies and International Order. Ithaca, NY: Cornell University Press.

Lesage, Dries, Thijs Van de Graaf, and Kirsten Westphal. 2010. Global Energy Governance in a Multipolar World. Surrey, UK: Ashgate.

Li, Quan. 2009. Democracy, Autocracy, and Expropriation of Foreign Direct Investment. Comparative Political Studies 42 (8):1098-127.

Lieber, Robert J. 1992. Oil and Power after the Gulf War. International Security 17 (1):155-76.

MacAvoy, Paul W. 1982. Crude Oil Prices as Determined by OPEC and Market Fundamentals. Pensacola, FL: Ballinger.

Mankiw, N. Gregory. 2011. Principles of Economics. Mason, OH: South-Western Cengage Learning.

Martin, Lisa L, and Beth Simmons. 1998. Theories and Empirical Studies of International Institutions. International Organization 52 (4):729-57.

McNamara, Kathleen. 2002. Rational Fictions: Central Bank Independence and the Social Logic of Delegation. West European Politics 25 (1):47-76.

Meyer, John W., and Brian Rowan. 1977. Institutionalized Organizations: Formal Structure as Myth and Ceremony. American Journal of Sociology 83 (2):340-63.

Moran, Theodore H. 1982. Modeling OPEC Behavior: Economic and Political Alternatives. In OPEC Behavior and World Oil Prices, edited by James. M. Griffin and David J. Teece, 94-130. London: Allen and Unwin. 
1987. Managing an Oligopoly of Would-Be Sovereigns: The Dynamics of Joint Control and Selfcontrol in the International Oil Industry Past, Present, and Future. International Organization 41 (4): 575-607.

Morrison, James Ashley. 2012. Before Hegemony: Adam Smith, American Independence, and the Origins of the First Era of Globalization. International Organization 66 (3):395-428.

Organization of the Petroleum Exporting Countries (OPEC). 2010. OPEC Bulletin. October. Vienna, Austria: OPEC. OPEC Bulletin, October 2010: 810.

Osborne, D.K. 1976. Cartel Problems. American Economic Review 66 (5):835-44.

Parra, Francisco. 2004. Oil Politics: A Modern History of Petroleum. New York: I.B. Tauris.

Qaimmaqami, Linda, and Edward Keefer, eds. 2011. Foreign Relations of the United States, 1969-1976, Volume 36, Energy Crisis, 1969-1974. Washington, DC: US Government Printing Office.

Reinker, Kenneth S. 2005. Recent Development: NOPEC: The No Oil Producing and Exporting Cartels Act of 2004. Harvard Journal on Legislation 42 (Winter): 285.

Reynolds, Douglas B., and Michael K. Pippenger. 2010. OPEC and Venezuelan Oil Production: Evidence Against a Cartel Hypothesis. Energy Policy 38 (10):6045-55.

Richardson, Bill. 2005. Between Worlds: The Making of an American Life. New York: Penguin.

Rose, Andrew K. 2004. Do We Really Know That the WTO Increases Trade? American Economic Review 94 (1):98-114.

- 2007. Do We Really Know That the WTO Increases Trade? Reply. American Economic Review 97 (5):2019-25.

Ross, Michael, and Erik Voeten. 2011. Unbalanced Globalization in the Oil Exporting States. Paper presented at the 107th annual meeting of the American Political Science Association, 3 September, Seattle, WA.

Rudra, Nita, and Nathan M. Jensen. 2011. Globalization and the Politics of Natural Resources. Comparative Political Studies 44 (6):639-61.

Sampson, Anthony. 2009 [1974]. The Seven Sisters: The Great Oil Companies and the World They Shaped. London: PFD.

Seymour, Ian. 1980. OPEC: Instrument of Change. New York: Macmillan.

Shaffer, Brenda. 2009. Energy Politics. Philadelphia: University of Pennsylvania Press.

Sikkink, Kathryn. 2011. The Justice Cascade: How Human Rights Prosecutions Are Changing World Politics. 1st ed. New York: Norton.

Simmons, Beth A., and Daniel J. Hopkins. 2005. The Constraining Power of International Treaties: Theory and Methods. American Political Science Review 99 (4):623-31.

Simpson, John L. 2008. Do the Major Oil Companies Anticipate OPEC Production Allocations? Paper presented at the 21st Australasian Finance and Banking Conference, August, Sydney, Australia. Available at <http://papers.ssrn.com/sol3/papers.cfm?abstract_id=1162084>. Accessed 12 July 2012.

Skeet, Ian. 1991. OPEC: Twenty-Five Years of Prices and Politics. Cambridge: Cambridge University Press.

Smith, James. 2005. Inscrutable OPEC? Behavioral Tests of the Cartel Hypothesis. Energy Journal 26 (1): 51-82.

2008. Organization of the Petroleum Exporting Countries (OPEC). In The New Palgrave Dictionary of Economics, edited by Steven N. Durlauf and Lawrence E. Blume, 229-32. New York: Palgrave Macmillan.

- 2009. World Oil: Market or Mayhem? Journal of Economic Perspectives 23 (3):145-64.

Snidal, Duncan. 1985. Coordination Versus Prisoners' Dilemma: Implications for International Cooperation and Regimes. American Political Science Review 79 (4):923-42.

Sovacool, Benjamin K. 2011. The Routledge Handbook of Energy Security. New York: Routledge.

Stobaugh, Robert B. 1975. The Oil Companies in the Crisis. Daedalus 104 (4):179-202.

Teece, David J. 1982. OPEC Behavior: An Alternative View. In OPEC Behavior and World Oil Prices, edited by James. M. Griffin and David J. Teece, 64-93. London: Allen and Unwin. 
Verrastro, Frank, David Pumphrey, Alan S. Hegburg, and Marshall Nannes. 2011. "NOPEC" Legislation and US Energy Security. Washington, DC: Center for Strategic and International Studies. Available at <http://csis.org/publication/nopec-legislation-and-us-energy-security>. Accessed 5 November 2011.

Victor, David. 2008. OPEC Is Irrelevant: The Once All-Powerful Oil Cartel Now Mostly Just Rides the Waves of Supply and Demand. Newsweek. 1 August.

von Stein, Jana. 2005. Do Treaties Constrain or Screen? Selection Bias and Treaty Compliance. American Political Science Review 99 (4):611-22.

Waghorn, Jonathan, Matthew Lanstone, Mark A. Lacey, and Arjun N. Murti. 2006. Global Energy: 125 Projects to Change the World. Goldman Sachs Group.

Wallander, Celeste. 2000. Institutional Assets and Adaptability: NATO After the Cold War. International Organization 54 (4):705-35.

Wilpert, Gregory. 2007. Changing Venezuela: The History and Policies of the Chavez Government. London: Verso.

Woolsey, R. James, and Anne Korin. 2008. How to Break Both Oil's Monopoly and OPEC's Cartel. Innovations: Technology, Governance, Globalization 3 (4):35-38.

Yergin, Daniel. 2008. The Prize: The Epic Quest for Oil, Money, and Power. New York: Free Press. 